UNIVERSIDADE FEDERAL DE JUIZ DE FORA

FACULDADE DE ENFERMAGEM

PROGRAMA DE PÓS-GRADUAÇÃO EM ENFERMAGEM

MESTRADO EM ENFERMAGEM

Anna Karla Nascimento Lima

EDUCAÇÃO PERMANENTE COMO DISPOSITIVO DE GESTÃO DO SISTEMA DE SAÚDE

Juiz de Fora 


\title{
EDUCAÇÃO PERMANENTE COMO DISPOSITIVO DE GESTÃO DO SISTEMA DE
} SAÚDE

\begin{abstract}
Dissertação apresentada ao Programa de Pós-graduação em Enfermagem, da Universidade Federal de Juiz de Fora como requisito parcial a obtenção do grau de Mestre em Enfermagem. Área de concentração: Fundamentos Teóricos, Políticos e Culturais do Cuidado em Saúde e Enfermagem
\end{abstract}

Orientadora Prof $\stackrel{\text { a }}{\text {. Dr }}{ }^{\mathrm{a}}$. Denise Barbosa de Castro Friedrich 
Ficha catalográfica elaborada através do programa de geração automática da Biblioteca Universitária da UFJF, com os dados fornecidos pelo(a) autor(a)

Nascimento Lima, Anna Karla.

- EDUCAÇÃO PERMANENTE COMO DISPOSITIVO DE GESTÃO DO SISTEMA DE SAÚDE / Anna Karla Nascimento Lima. - 2019.

$86 \mathrm{p}$

Orientadora: Denise Barbosa de Castro Friedrich

Dissertação (mestrado acadêmico) - Universidade Federal de Juiz de Fora, Faculdade de Enfermagem. Programa de Pós Graduação em Enfermagem, 2019.

1. Educação Permaente em Saúde. 2. Sistema Único de Saúde. 3. Superintendência de Saúde. I. Barbosa de Castro Friedrich, Denise, orient. II. Titulo. 


\title{
EDUCAÇÃO PERMANENTE COMO DISPOSITIVO DE GESTÃO DO SISTEMA DE SAÚDE
}

\begin{abstract}
Dissertação apresentada ao Programa de Pós-graduação em Enfermagem, da Universidade Federal de Juiz de Fora como requisito parcial a obtenção do grau de Mestre em Enfermagem. Área de concentração: Fundamentos Teóricos, Políticos e Culturais do Cuidado em Saúde e Enfermagem
\end{abstract}

Aprovada em 25 de junho de 2019

BANCA EXAMINADORA

Dr. ${ }^{\text {a }}$ Denise Barbosa de Castro Friedrich (orientadora)

Universidade Federal de Juiz de Fora

Dr. ${ }^{\text {a }}$ Elaine Cristina Dias Franco

Universidade Federal de São João del Rei

Dr. Fabio da Costa Carbogim

Universidade Federal de Juiz de Fora

Dr. a Vânia Aparecida da Costa Oliveira

Universidade Federal de São João del Rei

Dr. ${ }^{\text {a }}$ Edna Aparecida Barbosa de Castro

Universidade Federal de Juiz de Fora 
Dedico este trabalho aos meus avós, Renato e Iracy, que me ensinaram os verdadeiros valores da vida, e a quem amo incondicionalmente. Ao meu amado esposo Leonardo, pelo amor e pela compreensão nos momentos difíceis. À minha querida orientadora Denise, pela paciência, carinho, confiança e dedicação dispensadas ao longo de toda a minha trajetória acadêmica e profissional. E por fim, a todos os professores, que mesmo diante aos inúmeros desafios impostos pelo cotidiano, não se abatem, mas pelo contrário, continuam acreditando na educação, como instrumento de promoção da qualidade de vida e justiça social. 


\section{AGRADECIMENTOS}

Primeiramente, agradeço a Deus, por renovar minhas forças a cada manhã, e por me inspirar na busca de todos os meus sonhos.

Aos meus avós Renato e Iracy pelo amor sem medida devotado a mim, desde o meu nascimento. Hoje a lembrança saudosa desse amor, é o que me mantém de pé, dia após dia.

Ao meu amado esposo Leonardo, por todo amor, companheirismo, e compreensão, e a toda sua família, a qual já é minha família também.

À minha querida orientadora Prof ${ }^{a}$. Denise Barbosa de Castro Friedrich pelo incentivo, apoio, e confiança para a realização deste trabalho, bem como por todo carinho, amizade e compreensão durante toda a minha formação.

Aos professores, Fábio, Edna, Elaine e Vânia, que gentilmente se dispuseram à colaborar com este momento.

À Secretária de Estado de Saúde - Minas Gerais, que através do Diretor do desenvolvimento de Pessoas, Sr. Helton Guerra, colaborou intensamente com o desenvolvimento deste estudo, bem como à todos os profissionais das SRS's e GRS's que participaram da pesquisa.

Aos meus tão queridos amigos da "TURMA DIAMANTE", que tornaram esta caminhada mais leve e agradável, em especial, ao querido amigo Lucas, pelo apoio e parceria no desenvolvimento deste trabalho.

A todos os funcionários da Universidade Federal de Juiz de Fora, em especial às secretárias Anna e Wanessa, que de forma ímpar contribuíram com minha formação.

A todos os professores pela confiança e motivação, não só aos desta etapa, mas a todos aqueles que me permitiram chegar até aqui.

Aos meus amados alunos, por alegrarem os meus dias, e por me inspirarem nesta árdua jornada da docência.

E por esta vitória alcançada, a todos muito obrigada!!! 
Com licença poética

Quando nasci um anjo esbelto, desses que tocam trombeta, anunciou: vai carregar bandeira.

Cargo muito pesado pra mulher, esta espécie ainda envergonhada. Aceito os subterfúgios que me cabem, sem precisar mentir.

Não sou tão feia que não possa casar, acho o Rio de Janeiro uma beleza e ora sim, ora não, creio em parto sem dor. Mas o que sinto escrevo. Cumpro a sina. Inauguro linhagens, fundo reinos -- dor não é amargura.

Minha tristeza não tem pedigree, já a minha vontade de alegria, sua raiz vai ao meu mil avô. Vai ser coxo na vida é maldição pra homem.

Mulher é desdobrável. Eu sou. (Prado, 1993. p. 11) 


\section{RESUMO}

O presente trabalho, trata-se de um estudo de natureza qualitativa, do tipo descritivo, cujo o objetivo geral, foi analisar a Educação Permanente em Saúde (EPS) como dispositivo de gestão para profissionais de saúde nas Superintendências e Gerências Regionais de Saúde de Minas Gerais. Neste, o cenário foi compreendido por 28 Superintendências e/ou Gerências Regionais de Saúde do estado de Minas Gerais, e os participantes foram 41 profissionais de saúde, que trabalham na gestão de projetos e programas desenvolvidos nestes espaços. A coleta de dados se deu entre os meses de dezembro de 2018 à março de 2019, por meio de um questionário semiestruturado, aplicado através formulários eletrônicos. Para finalização da coleta de dados, foi empregado o critério de adensamento teórico. Os conteúdos provenientes dos formulários, foram consolidados e tratados através das ferramentas do pacote office, e posteriormente analisados à luz da hermenêutica dialética. Os resultados encontrados foram organizados nas seguintes categorias: Compreensões sobre a educação permanente em saúde; A gestão em saúde como prática profissional cotidiana nas Superintendências Regionais de Saúde e Gerências Regionais de Saúde, e a gestão em saúde no contexto da formação profissional. Das categorias emergiram cinco núcleos de sentido, dos quais foi possível inferir que os participantes deste estudo compreendem a Educação Permanente em Saúde como um Processo de Ensino Aprendizado, de elevada importância no desenvolvimento de suas atividades cotidianas, entretanto demostram dificuldades em delimitar com clareza, o conceito e a aplicação da mesma em seus contextos de trabalho. Foram também evidenciadas, dificuldades estruturais e de gestão que limitam a consolidação da Educação Permanente em Saúde como dispositivo de gestão, bem como a necessidade de se repensar os modelos pedagógicos relacionados à temática, postos na atualidade. O estudo, visa contribuir com o fortalecimento das discussões a respeito da Política Nacional de Educação Permanente em Saúde, bem como, destaca-la como uma possibilidade de dispositivo de gestão no Sistema Único de Saúde, em especial, no que tange às necessidades das Superintendências e Gerencias de Saúde.

Palavras-chave: Educação Continuada. Pessoal de Saúde. Enfermagem. 


\begin{abstract}
The present work is a qualitative descriptive study, whose general objective was to analyze Permanent Health Education (EPS) as a management device for health professionals in the Minas Gerais Superintendences and Regional Health Management. General. In this scenario, the scenario was comprised of 28 Superintendencies and / or Regional Health Management of the state of Minas Gerais, and the participants were 41 health professionals, who work in the management of projects and programs developed in these spaces. Data collection took place between December 2018 and March 2019, through a semi-structured questionnaire, applied through electronic forms. To finalize the data collection, the criterion of theoretical densification was employed. The contents of the forms were consolidated and treated through the office package tools, and later analyzed in the light of dialectical hermeneutics. The results were organized into the following categories: Understandings about continuing health education; Health management as a daily professional practice in the Regional Health Superintendencies and Regional Health Management, and health management in the context of vocational training. From the categories emerged five nuclei of meaning, from which it was possible to infer that the participants of this study understand Permanent Health Education as a Learning Teaching Process, of high importance in the development of their daily activities, however, they show difficulties in clearly defining concept and its application in their work contexts. Structural and management difficulties that limit the consolidation of Permanent Health Education as a management device were also highlighted, as well as the need to rethink the current pedagogical models. The study aims to contribute to the strengthening of the discussions about the National Policy of Permanent Education in Health, as well as highlighting it as a possibility of management device in the Unified Health System, especially regarding the needs of the Superintendencies. and Health Management.
\end{abstract}

Keywords: Continuing Education. Personal Health. Nursing. 


\section{LISTA DE TABELAS}

QUADRO 1: Questionário Online Versão I ..................................................36

QUADRO 2: Questionário Online Versão Final ................................................40

QUADRO 3: Apresentação das Categorias e Núcleos de Sentido .........................43 


\section{LISTA DE ABREVIATURAS E SIGLAS}

BDTIII-III- Bolsa de Desenvolvimento Tecnológico e Incentivo à Inovação III

BIC- Bolsa de Iniciação Científica

CGR- Colegiados de Gestão Regionais

CIES- Comissões Permanentes de Integração Ensino-Serviço

CIR- Comissões Intergestoras Regionais

CNE- Conselho Nacional de Educação

CNS- Conselho Nacional de Saúde

CONASEMS- Conselho Nacional de Secretarias Municipais de Saúde

CONASS- Conselho Nacional de Secretários de Saúde

DCN- Diretrizes Curriculares Nacionais

EC- Educação Continuada

ECS- Educação Continuada em Saúde

EP- Educação Permanente

EPS- Educação Permanente em Saúde

ESF- Estratégia de Saúde da Família

FACENF- Faculdade de Enfermagem

FAPEMIG- Fundação de Amparo à Pesquisa do Estado de Minas Gerais

GAPESE- Grupo de Estudos e Pesquisas sobre Autocuidado e Processos

Educativos em Saúde e Enfermagem

GRS- Gerência Regional de Saúde

IBGE- Instituto Brasileiro de Geografia e Estatística

MS- Ministério da Saúde

NS- Núcleo de Sentido

OMS- Organização Mundial da Saúde

OPAS- Organização Pan-Americana da Saúde

PEPS- Polos de Educação Permanente em Saúde

PNEPS- Política Nacional de Educação Permanente em Saúde

PPSUS- Programa de Pesquisa para o SUS

SES- Secretaria Estadual de Saúde

SGTES- Secretaria de Gestão do Trabalho e da Educação em Saúde

SRS- Superintendência Regional de Saúde

SUS- Sistema Único de Saúde

TCC- Trabalho de Conclusão de Curso

TCLE- Termo de Consentimento Livre e Esclarecido

UF- Unidades Federativas

UFJF- Universidade Federal de Juiz de Fora

UFSJ- Universidade Federal de São João Del Rei 


\section{SUMÁRIO}

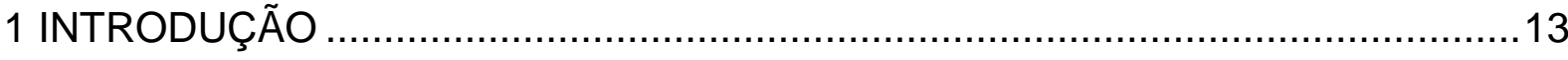

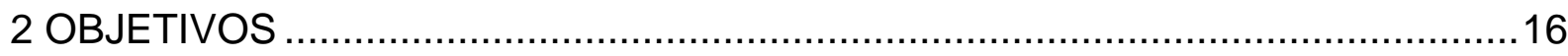

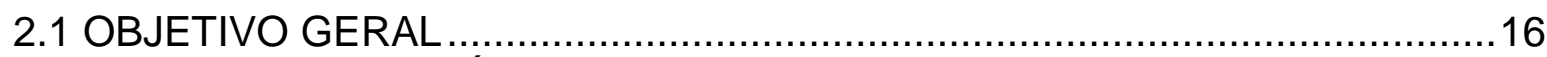

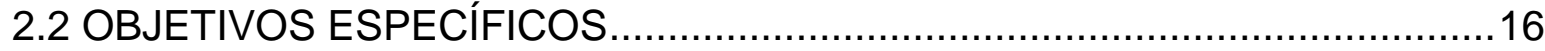

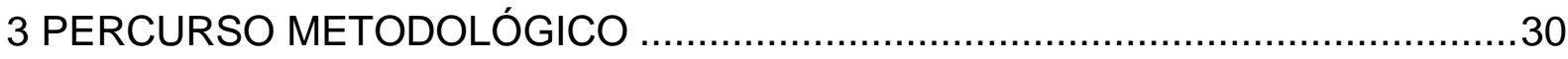

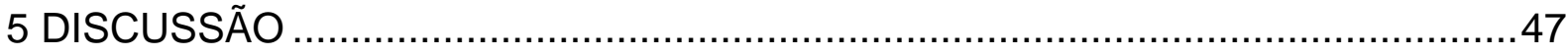

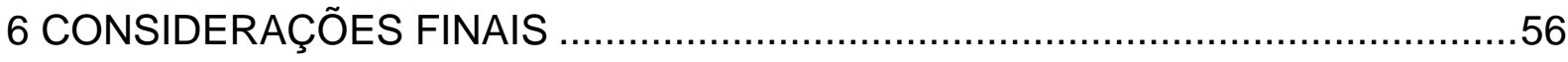

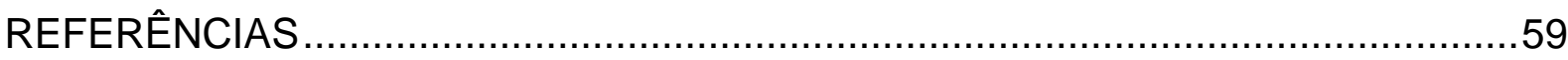

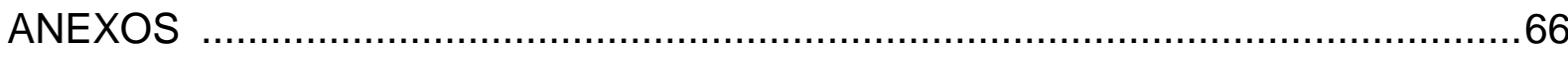




\section{INTRODUÇÃO}

A Educação Permanente (EP), tem como diretriz atender às necessidades sociais que emergem das constantes mudanças ocorridas no mundo, e assim preparar o homem em suas potencialidades individuais para os desafios contemporâneos (SMAHA; CARLOTO, 2010). Sob esta prerrogativa, as discussões relacionadas à temática da EP ganharam nas últimas décadas, força e centralidade em várias áreas do conhecimento humano, em especial na área da saúde, onde é vislumbrada como um caminho para a emancipação individual dos sujeitos, tornando-os capazes de assumirem o protagonismo de sua própria história, a partir da reflexão crítica sobre o contexto econômico, social, político e de saúde em que estão inseridos.

Ao refletir sobre a trajetória profissional que tenho traçado desde a graduação, percebo que por diversas vezes estive envolvida em ações de Educação Permanente em Saúde (EPS). Desde os primeiros momentos de inserção nos cenários práticos, até os campos de estágio obrigatórios para a obtenção do título de enfermeira, sempre desenvolvi ou participei de momentos de aprendizado conjunto, norteados pelos princípios da EPS, ainda que nestes momentos, por falta de aproximação com a temática, eu não os reconhecesse como tal.

Em minha primeira experiência profissional após a graduação, a Residência Multiprofissional em Atenção Hospitalar do Hospital Universitário de Juiz de Fora, novamente estive imersa em práticas de EPS, tendo em vista que nesta modalidade de formação, as atividades devem ser desenvolvidas a partir da transposição dos princípios da educação para a prática cotidiana do trabalho em saúde, caracterizando assim a formação em serviço.

Embora neste momento eu já me aproximasse dos conceitos e competências propostos pela EPS, a compreensão da mesma como política pública e possível dispositivo de gestão, ainda era distanciada da minha vivência cotidiana.

Ao final da Pós-Graduação Lato Sensu, ingressei no curso de mestrado acadêmico em Enfermagem, com a proposta de estudar a formação dos profissionais técnicos em enfermagem, me aproximando desta forma, da temática da EPS e de diversos autores que a propunham como dispositivo formativo e de gestão.

Ainda no mesmo ano de minha inserção no Programa de Pós Graduação Mestrado em Enfermagem da Universidade Federal de Juiz de Fora, foi publicado 
pelo Ministério da Saúde (MS), em parceria com a Fundação de Amparo à pesquisa de Minas Gerais (FAPEMIG), o edital 07/2017 do Programa de Pesquisa para o SUS (PPSUS), o qual, trata-se de uma iniciativa de fomento à pesquisa em saúde nas Unidades Federativas (UF) do país, e visa promover o desenvolvimento cientifico e tecnológico do sistema de saúde público brasileiro, atendendo as peculiaridades e especificidades de cada estado, contribuindo com a redução das desigualdades regionais de saúde (BRASIL, 2017).

Diante da oportunidade posta pelo edital, optamos em modificar o objeto de estudo pretendido até o momento, e submeter ao processo de financiamento, 0 trabalho, intitulado: "Educação permanente como dispositivo de gestão do Sistema Único de Saúde", cujo o objetivo geral, conforme o proposto no título, visa analisar a Educação Permanente como dispositivo de gestão do Sistema Único de Saúde, nas 28 Superintendências e Gerências Regionais de Saúde de Minas Gerais, através da compreensão como se dá o trabalho dos profissionais de saúde ali atuantes.

Dada a relevância da pesquisa, e o reconhecimento da eminente necessidade de estudo sobre a temática, reconhecida pela banca avaliadora do edital, a proposta foi aceita para financiamento, destacando-se como uma, da quarenta e nove propostas aceitas, dentre às 200 , submetidas ao edital.

Ressalta-se ainda que a proposta submetida ao edital 07/2017, trata-se de uma derivação do trabalho "Educação permanente como ferramenta de gestão do sistema único de saúde: a concepção dos enfermeiros", de autoria da Enfa. Ma. Luciana Teixeira Rossetti, desenvolvido no ano de 2015, durante sua Pós Graduação Stricto Sensu, Mestrado em Enfermagem, também na Faculdade de Enfermagem, da Universidade Federal de Juiz de Fora, e propõe uma ampliação dos cenários e das categorias profissionais investigados por Rosseti (2015).

Para que pudéssemos alcançar todos os objetivos propostos, a pesquisa contou com a colaboração de 07 pesquisadores e 03 bolsistas, dando origem à trabalhos de conclusão de curso e à dissertações de mestrados.

O presente estudo, trata-se de um dos muitos estudos desenvolvidos pelo GAPESE/UFJF (Grupo de Estudo e Pesquisa sobre Autocuidado e Processos Educativos em Saúde e Enfermagem), o qual, insere-se na linha de pesquisa: Fundamentos Teóricos, Políticos e Culturais do Cuidado em Saúde Enfermagem, do curso de Pós Graduação Stricto Sensu, Mestrado em Enfermagem, da Faculdade de Enfermagem, da Universidade Federal de Juiz de Fora (FACENF/UFJF). 
Nele, será discutido o contexto histórico da implementação PNEPS, bem como sua possível relevância nos processos de gestão do SUS, no âmbito das Superintendências e Gerências Municipais de Saúde do estado de Minas Gerais. Em seguida, serão descritos os objetivos que orientaram toda à pesquisa, bem como o detalhamento do percurso metodológico, e dos resultados obtidos através da análise dos questionários, analisados sob à luz da hermenêutica dialética, discutidos e alicerçados no referencial teórico proposto. Por fim, serão apresentadas as considerações finais, e uma reflexão acerca da educação permanente como dispositivo de gestão do Sistema Único de Saúde. 


\section{OBJETIVOS}

2.1 OBJETIVO GERAL

Analisar a Educação Permanente como dispositivo de gestão dos profissionais de saúde nas Superintendências e Gerências Regionais de Saúde de Minas Gerais.

\subsection{OBJETIVOS ESPECÍFICOS}

- Compreender como se dá o trabalho dos profissionais de saúde atuantes nas Superintendências e Gerências Regionais de Saúde de Minas Gerais;

- Descrever como os profissionais de saúde concebem a Educação Permanente como dispositivo de gestão; 


\section{REFERENCIAL TEÓRICO}

Historicamente, a formação dos profissionais de saúde tem sido norteada por modelos positivistas, conservadores e fragmentados que se distanciam das verdadeiras demandas da população, bem como do cuidado integral, ou seja do modelo de cuidado que compreende o indivíduo como um ser complexo, inserido em um contexto social, dando especial atenção às suas especificidades e demandas (SOUSA, 2015).

Tal paradigma, aponta para as lacunas existentes entre os modelos de ensino acadêmico e a assistência ofertada à população, reforçando a necessidade das discussões a respeito das mudanças na formação e atuação destes profissionais (GIGANTE, CAMPOS, 2016).

Vislumbrando a superação destas lacunas, a Política Nacional de Educação Permanente em Saúde (PNEPS) destaca-se como uma proposta de ação estratégica, que visa contribuir com a transformação e a qualificação das práticas de saúde, bem como, com a organização das ações, dos serviços, dos processos formativos e das práticas pedagógicas na formação e no desenvolvimento dos trabalhadores de saúde (BRASIL, 2004a).

Neste trabalho, será adotado o conceito de Educação Permanente em Saúde (EPS), proposto pela Política Nacional de Educação Permanente em Saúde (PNEPS), na qual a EPS, é definida "como uma proposta ético-político-pedagógica que visa transformar e qualificar a atenção à saúde, os processos formativos, as práticas de educação em saúde, além de incentivar a organização das ações e dos serviços numa perspectiva intersetorial" (BRASIL, 2004a).

Desde sua implantação, a PNEPS estrutura-se na articulação entre os conceitos de educação e trabalho em saúde, buscando a melhoria da qualidade da assistência, através do compromisso firmado entre gestores, equipes de saúde, instituições formadoras e a sociedade (BRASIL, 2004a).

Entretanto, antes que efetivamente sejam traçadas reflexões a cerca desta temática e de sua aplicabilidade à gestão do Sistema Único de Saúde brasileiro, tal como propõe o presente estudo, faz-se necessário que alguns conceitos relacionados ao mundo do trabalho e à educação, sejam rememorados.

Nesta revisão da literatura, será traçado um breve apanhado histórico sobre a origem e a consolidação da EPS enquanto política pública, vinculando-a às 
transformações em saúde vivenciadas pelas população brasileira nas últimas cinco décadas.

Considerando a "formação para o trabalho", a "formação para o conhecimento", e a "formação para a vida", como finalidades da EPS, (CECCIM, BRAVIN e SANTOS, 2009, p. 165), buscar-se-á ao longo do trabalho contextualizalas à lógica do trabalho de gestão do Sistema Único de Saúde (SUS) brasileiro, no âmbito das Superintendências e Gerencias Regionais de Saúde do estado de Minas Gerais.

Para que se possa compreender a finalidade de "formação para o trabalho" da EPS, primeiramente será preciso rememorar o conceito de trabalho e suas implicações na sociedade atual. Karl Marx (1867), em sua mais relevante obra, $O$ Capital, define trabalho como a essência da humanidade dos homens, e afirma que o homem, ao transformar a natureza, adequando-a a seus interesses, concomitantemente modifica a si mesmo (MARX, 1867).

Merhy e Franco (2014), corroboram, afirmando que toda atividade humana é um ato produtivo, capaz de produzir, criar ou modificar seu entorno, bem como elucidam o conceito, ao nos relembrarem que desde os primórdios da civilização, a humanidade utiliza-se do trabalho, como meio de transformação da natureza, de acordo com sua necessidade e/ou vontade.

Marx afirma que a ação humana pressupõe a vontade quem a executa, pois ao conceber a forma do objeto de seu trabalho, o homem antecipa também 0 significado à ele será atribuído, caracterizando assim, uma ação consciente e planejada, portanto, um ato intelectual. Sob esta ótica, o trabalho humano pode ser definido como uma ação intencional, pois ao final do processo temos como resultado o que já existia antes idealmente na imaginação do trabalhador" (MARX, 1867).

Para o autor, o trabalho caracteriza-se também como uma forma de organização social, na qual os indivíduos se reconhecem, reconhecem suas demandas coletivas, e reconhecem o potencial que possuem para intervir sobre elas, e dessa forma ao desenvolverem ações intencionais, a partir do reconhecimento das necessidades do um grupo ou comunidade, o homem firma-se como um ser social, que se utiliza do trabalho como fonte de humanização e libertação (MARX, 1867).

Neste sentido, torna-se adequada a transposição do conceito de trabalho proposto por Marx, ao campo da saúde, pois o homem quando compreendido como 
sujeito social, é capaz de transformar sua própria realidade a partir das necessidades emergidas pelo coletivo, permitindo-nos inferir sobre o seu papel frente às determinantes que condicionam à saúde de uma população.

Merhy e Franco (2014) afirmam que as concepções de trabalho, consolidam-se no campo da saúde, a partir do valor simbólico atribuído pelo homem, ao ato do cuidar, sendo as necessidades de saúde dos indivíduos e das coletividades, expressas pelas demandas de cuidado, seu objeto central.

Desta forma, tal como o trabalho em educação, o trabalho em saúde, não ocupa-se em produzir bens/produtos, mas expressa-se através da construção de 'relações intercessoras' que se dão no encontro entre o trabalhador e o usuário, devendo desta forma, ser entendido como um 'trabalho vivo em ato' (MERHY, FRANCO, 2014).

Ainda de acordo com Merhy e Franco (2014), o homem, deve ser compreendido como sujeito social, ou seja, como um ser biológico, social e autônomo, dotado de uma subjetividade complexa, o qual imerso na história e na sociedade, busca através do processo reflexivo, reagir ao seu contexto. Desta forma, ao compreendermos o trabalhador de saúde como um sujeito coletivo, admitimos também, que ele está constantemente imerso em um processo de transformação, criação e compartilhamento de seu saber.

A segunda finalidade da EPS, é definida como a "formação para o conhecimento", esta guarda profunda relação com as concepções de educação em saúde e educação para saúde, assim, para que se possa compreende-la, faz-se necessário primeiramente conceituar o termo educação, o qual sob a ótica de Paulo Freire, deve ser compreendido como uma relação dialógica, processual, e cotidiana, cujo o principal objetivo é a mediação significativa da realidade do educando, com o saber teórico à ser apreendido (FREIRE, 1983).

Freire propõe que ensinar, é dar forma e alma à um conhecimento indeciso, inacabado ou acomodado já existente nos indivíduos, o qual ocorre formal ou informalmente, dotado de finalidade ou despretensiosamente nas relações humanas, devendo desta forma ser compreendido a partir da extrapolação da lógica de formação exclusiva nas salas de aula, alcançando os indivíduos onde quer que eles estejam (FREIRE, 1983).

Já a expressão educação para a saúde, define o conjunto de saberes técnicos desenvolvidos pelos profissionais da saúde afim de que atuem no processo saúde- 
doença das pessoas, famílias e comunidades. Sua origem e consolidação no cenário brasileiro, datam do final século XIX, período em que as práticas educativas em saúde tinham caráter basicamente higienista, cuja a finalidade centrava-se em contribuir com o manutenção de uma população saudável e produtiva (BATISTA, 2011).

Neste sentido, a formação dos profissionais atuantes na área da saúde norteava-se pela lógica biologicista e sanitarista, que através de práticas verticalizadas, controladoras e normativas de educação, perpetuavam a ideia de incapacidade dos indivíduos para cuidarem de sua própria saúde (BATISTA, 2011).

Somente a partir do século $\mathrm{XXI}$, impulsionado pelo entendimento do conceito ampliado de saúde, teve início o movimento de transformação das práticas de formação dos profissionais de saúde. A partir de então, olhar para saúde deixou de ser puramente curativista, e as ações de prevenção à doenças ganham espaço, começa-se à valorizar a promoção da saúde e do bem estar, e os sujeitos passam a ser vistos com autonomia e responsabilidade, tornando-se atores do seu cuidado, refletindo na formação de profissionais engajados e comprometidos com o bem estar social dando origem ao que hoje compreendemos por educação em saúde.

Para Silva (2017), a Educação em Saúde deve ser compreendida a partir do conceito ampliado de saúde, proposto pela OMS, devendo considerar a realidade dos sujeitos e o contexto no qual estão inseridos, afim de propor e implementar políticas públicas, que favoreçam a criação de ambientes adequados e a reorientação dos serviços de saúde, para que ofertem além de tratamentos clínicos e curativos, ações de promoção à saúde integral, orientadas a partir de propostas pedagógicas libertadoras, comprometidas com o desenvolvimento da solidariedade e da cidadania dos sujeitos, e cuja essência esteja fundamentada na melhoria da qualidade de vida.

Desta forma, a partir da articulação dos conceitos anteriormente apresentados pode-se alcançar compreensão da terceira finalidade da EPS, a qual é definida como a "formação para a vida", e fundamenta-se na instrumentalização dos indivíduos para que assumam o protagonismo de sua existência, tornando-os capazes de decidirem criticamente sobre as questões permeiam seu cotidiano (BATISTA, 2011).

Neste sentido, ao colocarmos o trabalho em saúde sob as lentes da educação, percebemos que a articulação dos saberes e das concepções ampliadas destes dois campos são imprescindíveis para que possamos compreender e contribuir com o aprimoramento da formação dos trabalhadores do SUS, bem com as ações de gestão, que nele são desenvolvidas. 
Desta forma, a EPS, caracteriza-se como um conceito pedagógico, que busca favorecer as relações entre ensino, serviço, e atenção à saúde, atuando nos eixos de formação, gestão, desenvolvimento e controle social (EVASHWICK, 2013), bem como busca contribuir com a adequação da formação dos trabalhadores em saúde, às reais necessidades do usuário (re)significando o perfil de atuação dos mesmos, através de bases teóricas alicerçadas na autonomia, na cidadania, e na subjetividade dos atores (BRASIL, 2009).

O conceito de Educação Permanente em Saúde, deriva-se do conceito pedagógico de "Educação Permanente" (EP), que aparece pela primeira vez, em 1955, na França, através de um projeto de reforma educacional, elaborado pela Liga Francesa de Ensino, o qual dispunha sobre a importância de se assegurar a manutenção da instrução dos cidadãos mesmo após a escola, afim de que se possa prolongar, completar, renovar ou readaptar a formação profissional e intelectual dos indivíduos (GADOTTI e FREIRE, 1987).

No ano seguinte, visando à qualificação dos trabalhadores no pós-guerra, tal projeto, que dispunha em suma, sobre o prolongamento da escolaridade obrigatória e a reforma do ensino público francês, foi oficializado pelo Ministro da Educação Nacional René Billères, no documento Ministro Educacional, dando assim, início à uma nova lógica de formação profissional, que posteriormente seria aplicada à diversos campos do saber, dentre eles o da saúde (GADOTTI e FREIRE, 1987).

A origem da EPS, guarda também, profunda relação com a reorganização das relações de trabalho no mundo pós moderno, em especial com a incorporação do modelo empresarial Toyotista, surgido no Japão, em 1945, e difundido pelo mundo a partir dos anos 70, o qual, ao contrário do fordismo, que através de práticas de trabalho repetitivas e desprovidas de sentidos, minimizava a dimensão intelectual do trabalho, cria uma lógica integrativa entre o operário e a organização do trabalho (LEMOS, 2016).

Ancorada em teorias pedagógicas que objetivam o desenvolvimento integral dos trabalhadores, a EP constitui-se como uma importante estratégia de complementação/superação a propostas educativas reducionistas e tecnicistas, socialmente postas na atualidade, na qual almeja-se a consolidação de práxis transformadoras capazes de promover à resolutividade dos problemas e a democratização dos espaços de trabalho (CECCIM, 2005). 
Tomando por base os princípios da EP, pode-se compreender a transmutação deste conceito para campo da saúde, bem como sua aplicabilidade aos processos de gestão do SUS. A partir de tal prerrogativa, a Organização Pan-americana de Saúde (OPAS), resgatou junto à Unesco, as bases fundamentais da Educação Permanente, que outrora eram aplicadas exclusivamente na área da educação, sistematizando-as sob uma perspectiva teórica e metodológica para a constituição de Programas de Educação Permanente em Saúde (BATISTA, 2011).

Historicamente, temos na 1a Conferência Pan-americana sobre Planejamento de Recursos Humanos em Saúde, ocorrida em 1973, no Canadá, o marco inicial a respeito dos primeiros debates relacionados à da necessidade emergente de construção de um novo modelo pedagógico que abarcasse as necessidades impostas pelos serviços de saúde, contribuísse com a melhoria da formação de seus profissionais, e traspusessem o modelo hegemônico de educação vigente. (LOPES et al, 2007).

No Brasil, com a expansão do sistema de saúde público, ocorrida nos anos 1970, evidenciou-se a necessidade, de um modelo político-pedagógico que viabilizasse o diálogo entre o ensino e os serviços de saúde, afim de que se ultrapassasse a lógica de formação em saúde, baseada em métodos transmissivos de conhecimento, via de regra aplicados em cursos pontuais de atualização e capacitação de categorias profissionais especificas, fora do ambiente de trabalho (SILVA, 2017).

A partir da década de 1980, em resposta à emergente necessidade de reconfiguração do modelo educacional posto, a EPS passa a ser vista como uma estratégia para a reordenação das práticas e das políticas de formação, atenção e gestão em saúde, tendo como referência o denominado "Quadrilátero da Educação Permanente em Saúde" (CECCIM, 2005), isto é, ensino, gestão, atenção e controle social, sendo assim implementada em consonância com princípios de universalidade, equidade e integralidade do SUS, bem como com suas diretrizes de descentralização e participação popular (BRASIL, 1988).

De acordo com a Organização Pan-americana de Saúde- OPAS, a proposta de uma política brasileira de capacitação permanente de pessoal para a saúde pode ser compreendida em três momentos distintos (OPAS, 1990).

O primeiro, teve início em 1996, quando foi publicado o primeiro edital de convocação dos Estados para a apresentação de projetos de desenvolvimento de 
recursos humanos, caracterizando um conjunto de iniciativas voltadas para o fortalecimento da estratégia de Saúde da Família e da Atenção Básica. Em 1997, foram criados os Polos de Formação, Capacitação e Educação Permanente para as equipes de Saúde da Família, e a partir deles, surgiram propostas de aproximação do preceito constitucional que define a ordenação dos Recursos Humanos para a Saúde como atributo do SUS (BRASIL, 2004).

O segundo momento, deu-se a partir de 2004, com a criação da Política Nacional de Educação Permanente em Saúde, instituída por meio da Portaria no 198/04, onde a Educação Permanente em Saúde passa a ser reconhecida pelo Ministério da Saúde, como estratégia de transformação das práticas de formação, de atenção, de gestão, de formulação de políticas, de participação popular e de controle social no setor da Saúde (BRASIL, 2004).

Deste segundo momento, emergiram a Secretaria de Gestão do Trabalho e da Educação na Saúde (SGTES) no Ministério da Saúde e os Polos de Educação Permanente em Saúde (PEPS), responsáveis pela difusão da proposta da PNEPS, pelos diferentes municípios brasileiros (LEMOS, 2016). De acordo com o Ministério da Saúde (2004), as principais responsabilidades dos PEPSs, fundamentavam-se na identificação das necessidades de formação e desenvolvimento dos trabalhadores de saúde, bem como a mobilização dos gestores na busca de uma maior integração entre os diferentes pontos da rede de atenção à saúde.

Além destas, também eram atribuições dos PEPSs, propor políticas e estabelecer negociações nos níveis interinstitucional e intersetorial orientadas pelos princípios do SUS; estimular a criação de políticas com vistas à formação e desenvolvimento dos docentes; articular e estimular a transformação das práticas de saúde e de educação na saúde no conjunto do SUS e das instituições de ensino, tendo em vista a implementação das Diretrizes Curriculares Nacionais (DCN) para o conjunto dos cursos da área da saúde e a transformação de toda a rede de serviços e de gestão em rede-escolas; estabelecer a pactuação e a negociação permanente entre os atores das ações e serviços do SUS, docentes e estudantes da área da saúde; estabelecer relações cooperativas com as outras articulações locorregionais nos estados e no país (BRASIL, 2004).

O Terceiro Momento, delineado pela OPAS, se desdobra a partir de 2006, quando o Ministério da Saúde promulga, através da portaria no 399, de 22 de fevereiro de 2006, o Pacto pela Saúde. De acordo com Batista (2011), a grande 
mudança trazida por esta portaria, ocorreu nos espaços regionais de planejamento e gestão, os quais tomaram a forma de Colegiados de Gestão Regional (CGR), onde participam todos os gestores dos territórios abrangidos pelas regiões de saúde, reforçando os princípios da PNEPS.

Em 2007, visando definir novas diretrizes e estratégias para a implantação da Política Nacional de Educação Permanente em Saúde, o Ministério da Saúde, juntamente com o Conselho Nacional de Secretários de Saúde (CONASS) e o Conselho Nacional de Secretarias Municipais de Saúde (CONASEMS), discutiram e implementaram a Portaria n 198, a qual, no dia 22 de agosto de 2007, foi republicada pelo Diário Oficial da União, sob o número 1996 (BRASIL, 2007).

As principais mudanças trazidas por essa portaria foram, a adequação do Pacto pela Saúde, dando maior protagonismo ao Colegiado de Gestão Regional, a descentralização dos recursos financeiros, e a vinculação das ações de desenvolvimento dos trabalhadores do SUS aos planos da Educação Permanente em Saúde, nos âmbitos municipal, regional ou estadual (CUNHA e MAGAJEWSKI, 2012).

A Portaria, definiu ainda, que a condução regional da PNEPS se daria por meio dos Colegiados de Gestão Regional (CGR), atualmente denominados Comissões Intergestoras Regionais (CIR) com a participação de Comissões Permanentes de Integração Ensino-Serviço (CIES), os quais, deveriam apoiar-se mutuamente e consolidar o processo de gestão compartilhada das redes regionalizadas de serviços de saúde (BRASIL, 2007).

Ao longo de sua trajetória de consolidação, a PNEPS, transpôs o caráter prioritariamente educacional que inicialmente lhe foi outorgado, adquirindo um forte aspecto gerencial e organizacional dentro dos serviços de saúde, tendo como eixo estruturante os processos educativos, e as relações interpessoais dadas através dele (BRASIL, 2007).

Objetivando (re)significar o trabalho em saúde, com ênfase na formação qualificada dos profissionais e na qualidade da assistência, a PNEPS, busca através da construção coletiva, do diálogo e da reflexão sobre a prática, estabelecer-se também, como um dispositivo de gestão, capaz de promover a participação ativa dos trabalhadores em seu próprio processo de aprendizagem (BRASIL, 2007).

A definição clássica atribuída gestão, guarda profunda relação com o termo administração, sendo inclusive, por alguns dicionários considerados como 
sinônimos, tal como ocorre no Houaiss - Dicionário da Língua Portuguesa, onde gestão/ administração referem-se ao: "Ato ou efeito de administrar; ação de governar ou gerir empresa, órgão público [...]. Exercer mando, ter poder de decisão (sobre), dirigir, gerir" (HOUAISS, 2001).

Todavia a gestão em saúde, não pode ser entendida apenas como a aplicação pura do vocábulo gestão, ao campo da saúde, pois sua compreensão integral envolve conhecimentos específicos, utilizados no complexo manejo das organizações e redes de saúde.

Segundo Lorenzetti (2012) gestão em saúde, é o conhecimento cientifico aplicado no manejo das organizações de saúde, envolvendo a gerência de redes, das esferas públicas de saúde, e demais instituições e serviços de saúde. Florês (2018), traz que a gestão em saúde deve ser entendida com um processo que cria políticas sanitárias, elege programas que viabilizem tais políticas, além de prover recursos, fiscalizar e avaliar os programas e ações em saúde.

Para Campos; Campos (2009), a gestão em saúde abrange três grandes dimensões, sendo elas: os espaços de cuidado indireto; as instituições de saúde; e os espaços de formação profissional, devendo todos estes trabalharem em sintonia, visando a consolidação de redes de serviços de saúde eficazes, que ofereçam à população uma assistência universal, integral, equânime, de qualidade e eficiente para as necessidades de saúde da população.

Desta forma, é atribuída à gestão a responsabilidade da coordenação dos processos de trabalho e da organização dos sistemas de saúde, a partir dos princípios da administração, planejando, organizando, direcionando, controlando e avaliando os recursos e os meios, para que os objetivos propostos sejam alcançados. (CAMPOS; CAMPOS, 2009).

Entretanto não se faz rara, a constatação de que a gestão em saúde brasileira, ainda esteja alicerçada em modelos tradicionais e burocráticos de administração, fazendo com que as ações e políticas públicas, se distanciem das demandas sociais de saúde, estabelecendo assim, um grande entrave no sistema.

Neste sentido, evidencia-se a necessidade de uma reflexão sobre novas propostas de gestão e gerência em saúde, as quais que centralizem o processo de trabalho, o trabalhador e o cliente, bem como estejam pautadas em princípios éticos e democráticos (SPAGNOL, 2005) 
Desta forma, ao reconhecermos, as fragilidades dos modelos de educação e gestão em saúde tradicionalmente estabelecidos, evidenciamos a necessidade de implementação e fortalecimento de modelos educativos integradores, que potencializem a autonomia do trabalhador, tais como a PNEPS.

Tendo como princípio a gestão democrática e participativa, a Política Nacional de Educação Permanente em Saúde, busca romper com a verticalidade dos serviços de saúde, através da resolução compartilhada dos problemas encontrados do ambiente de trabalho, e para isto envolve a estruturação, a organização e a inserção do trabalhador no espaço de trabalho, bem como a atuação crítica, reflexiva, socialmente comprometida e tecnicamente competentes de todos os atores envolvidos (SILVA, 2005).

Segundo Silva (2017), para que alcancem efetividade nos serviços de saúde, as ações de EPS devem considerar as relações de trabalho ali existentes, proporcionando o desenvolvimento de um processo educativo que possibilite a reflexão sobre o porquê fazer, para que fazer e para quem fazer, levando os profissionais a buscarem coletivamente alternativas para mudanças substanciais na prática cotidiana, visando atender às necessidades de saúde da população.

Para Davini (2009), a EPS trata-se, de uma pedagogia problematizadora, a qual fundamenta-se no uso de metodologias ativas de conhecimento. Segundo o mesmo autor, problematizar significa "pensar a prática", que pressupõe romper com a lógica individual, e basear-se em uma relação dialógico-dialética, a qual proporciona que todos aprendam juntos e permite uma maior integração entre a equipe. Ainda de acordo com Davini (2009), por não haver relação de superioridade entre o educador e o educando, a pedagogia problematizadora permite ainda, a aproximação entre as esferas profissional e afetiva, fortalecendo os compromissos sociais e profissionais, desenvolvendo a consciência de grupo e contribuindo para o fortalecimento das identidades profissionais.

Temos assim, que as propostas educativas, congruentes à PNEPS, devem ser desenvolvidas a partir das necessidades evidenciadas pelos sujeitos, em seu processo de trabalho e na utilização de preceitos educativos problematizadores, tais como a aprendizagem significativa (MORAES, 2015). De acordo com Silva (2014), a aprendizagem significativa se dá quando um novo conhecimento é construído levando em consideração aqueles que o aprendiz, já possui previamente, de modo que faça sentido em suas práticas e o torne ativo no processo educativo. 
Ribeiro e Motta (1996), vão além, e afirmam que a aprendizagem não é possível se os atores não tomam consciência do problema ou se nele não se reconhecem. Desta forma, podemos inferir que a consolidação da PNEPS através de práticas problematizadoras, implica necessariamente em estimular, nos trabalhadores, transformações em seu modo de agir e pensar, envolvendo-os ativamente na dinâmica das instituições, num movimento de horizontalização de saberes e decisões.

Entretanto, embora a PNEPS, se estabeleça como uma importante estratégia frente aos os desafios relacionados à gestão do SUS, reconhece-se que a integralidade de sua implementação, ainda é uma realidade distante. Inúmeros fatores relacionam-se com a dificuldade, dentre eles, o desinteresse do poder público, o apego exacerbado ao tradicionalismo, e até mesmo as especificidades regionais de um país tão grande quanto o Brasil.

Sobre este último, podemos destacar, as dimensões continentais de um país, com extensão territorial de cerca de $8.514 .876 \mathrm{Km}^{2}$, e população superior à 200 milhões de habitantes (IBGE, 2018), o qual apresenta em cada uma de suas regiões, variadas determinantes sociais, que influenciam diretamente no processo de saúdedoença da população, e inviabilizam que seja aplicado o mesmo formato de administração em todas às suas localidades.

Para minimizar esta dificuldade, o Ministério da Saúde, norteado pelos princípios organizativos do SUS, e fundamentado nas concepções da PNEPS, utiliza-se da estratégia de descentralização para alcançar uma gestão eficiente, que atenda as demandas locais e respeite as especificidades de cada região. Nesta lógica, atribui à cada uma das três esferas de poder, papéis específicos no processo de gestão do SUS. À União, é conferido o papel de coordenar os sistemas de saúde de alta complexidade e de laboratórios públicos, planejar e fiscalizar o SUS em todo o País, por meio do próprio Ministério da Saúde (BRASIL, 2011).

Aos governos estaduais, é dada à responsabilidade de criar políticas de saúde regionais e ajudar na execução das políticas nacionais, repasse de verbas aos municípios, coordenação de sua rede de laboratórios e hemocentros, bem como a definição e gerencia dos hospitais e locais de atendimentos complexos da região (BRASIL, 2011).

Aos municípios, cabe o dever garantir os serviços de atenção básica à saúde e prestar serviços em sua localidade, criar políticas de saúde locais e colaborar com 
a aplicação das políticas nacionais e estaduais. Os municípios devem ainda, organizar e controlar os laboratórios e hemocentros, bem como administrar os serviços de saúde da cidade (BRASIL, 2011).

Neste contexto, as Superintendências e Gerências Regionais de Saúde, encontram-se vinculadas à instancia Estadual, tendo por finalidade garantir em âmbito regional, a gestão do Sistema Estadual de Saúde, buscando a qualidade de vida da população, implementando políticas estaduais de saúde, assessorando, coordenando, monitorando e avaliando os serviços de saúde (BRASIL, 2011). De acordo com Castro (1992), as Secretarias de Estados de Saúde desenvolvem três movimentos básicos: transferência de serviços de saúde para os municípios; incorporação de serviços de saúde, e criação/ ampliação dos órgãos de gestão municipais.

Segundo o decreto $\mathrm{n}^{0}$ 45.812, de 14 de dezembro de 20111, art. $2^{\circ}$ a SES tem por finalidade formular, regular e fomentar as políticas de saúde pública no Estado de Minas Gerais, atuando em cooperação com os demais entes federados na prevenção, promoção, preservação e recuperação da saúde da população, competindo- Ihe: I - formular e coordenar a política estadual de saúde e supervisionar sua execução nas instituições que integram sua área de competência; II - monitorar, coordenar, avaliar e consolidar as informações sobre saúde no Estado; III - formular planos e programas em sua área de competência, observadas as determinações governamentais, em articulação com a Secretaria de Estado de Planejamento e Gestão; IV - gerenciar, coordenar, controlar e avaliar as políticas do Sistema Único de Saúde - SUS - no Estado; V - promover e coordenar o processo de regionalização e descentralização dos serviços e ações de saúde; VI - incentivar e fomentar a universalização da atenção primária à saúde, assegurando o acesso às redes de atenção; VII - normalizar e implantar as redes de atenção à saúde do SUS no Estado; VIII - formular, em caráter complementar, as políticas de assistência farmacêutica no Estado; IX - formular diretrizes para o planejamento das demandas assistenciais de saúde e o credenciamento de instituições para a prestação de serviços de saúde; $X$ - coordenar o monitoramento e a avaliação das formas de financiamento do SUS no Estado; XI - estabelecer normas, em caráter complementar, para o controle, a avaliação e a auditoria das ações e serviços de saúde no Estado; XII - coordenar e, em caráter complementar, executar ações e serviços de vigilância sanitária, epidemiológica, ambiental, nutricional e de saúde do 
trabalhador; XIII - coparticipar da formulação da política de saneamento básico; XIV - estimular a pesquisa e a incorporação de inovações científicas e tecnológicas no âmbito do SUS; XV - editar normas e estabelecer padrões, em caráter suplementar, de procedimentos de controle de qualidade para produtos e substâncias de consumo humano; XVI - editar, em caráter complementar, normas e regulamentos destinados à prevenção, promoção, proteção e recuperação da saúde da população no Estado; XVII - fomentar a gestão participativa do SUS; XVIII - exercer atividades correlatas; e XIX - exercer o poder de polícia no âmbito da sua competência.

Já as Superintendências e Gerências Regionais de Saúde, compete: I implementar as políticas estaduais de saúde em âmbito regional; II - assessorar a organização dos serviços de saúde nas regiões; III - coordenar, monitorar e avaliar as atividades e ações de saúde em âmbito regional; IV - promover articulações interinstitucionais; V - executar outras atividades e ações de competência estadual no âmbito regional; VI - implantar, monitorar e avaliar as ações de mobilização social na região. VII - exercer outras atividades correlatas.

Para que se possa efetivamente executar o conjunto de estratégias acima descrito, faz-se necessário um aparelho estatal eficiente e que promova a plena conversão dos gastos governamentais em resultados efetivos e mensuráveis para a sociedade mineira (BRASIL, 2013), neste sentido, as SRS's e GRS's se estabelecem como pontos de gestão estratégicos na rede de atenção à saúde do estado de Minas Gerais, auxiliando a governabilidade e descentralização do SUS (CAMPOS, 2017).

Entretanto, de acordo com Gomes; Barbosa; Ferla (2016), as SRSs e GRSs progressivamente tornaram-se estancias de gestão do SUS esvaziadas, que enfrentam na atualidade o desafio de repensarem e reorientarem, o processo de trabalho de seus gestores, em prol do fortalecimento das ações desenvolvidas junto à Atenção Primária. Frente a tal desafio, e tendo em vista, o importante papel que estes espaços desempenham na gestão dos serviços de saúde, justifica-se a relevância do presente estudo, na formulação de discussões relacionadas à temática e na formulação de estratégias mais ajustadas à pratica cotidiana destes profissionais. 


\section{PERCURSO METOdOLÓGICO}

Para que se pudesse analisar a Educação Permanente como dispositivo de gestão do SUS, no âmbito das Superintendências e Gerências Regionais de Saúde de Minas Gerais, optou-se por uma abordagem qualitativa, do tipo descritiva, a qual através relação entre os fatos e o contexto, permite-nos uma visão mais clara da realidade, proporcionando-nos maior familiaridade com o problema evidenciado (MINAYO, 2014).

Ainda de acordo com Minayo (2014), a pesquisa qualitativa possibilita ainda, uma visão mais realista da totalidade, pois ao mesmo tempo pode ir ao encontro da revelação de um significado consensual e instituir uma crítica acerca desse consenso e sua relação com o contexto, sendo de grande valia para o método de interpretação.

O cenário do presente estudo, foi composto pelas 28 Superintendências e Gerências Regionais de Saúde do Estado de Minas Gerais. Os participantes da pesquisa foram profissionais de saúde, com nível superior de educação, que trabalham nas SRS e GRS do estado, na gestão de projetos e programas desenvolvidos junto à Atenção Primária à Saúde, nos municípios compreendidos na área de abrangência destas instâncias, que após a leitura e assinatura do Termo de Consentimento Livre e Esclarecido - TCLE (Anexo A) se disponibilizaram à compartilhar suas experiências através do preenchimento do instrumento de coleta de dados do estudo.

Foram adotados como critérios de inclusão, ser trabalhador de saúde com nível de formação superior, contratado ou efetivo, atuante na gestão de projetos e programas desenvolvidos junto à Atenção Primária à Saúde nos municípios compreendidos na área de abrangência das SRS/ GRS estudadas; aceitar participar formalmente do estudo através da assinatura do Termo de Consentimento Livre e Esclarecido - TCLE (Anexo A).

Como critério de exclusão, foi utilizado, o fato do trabalhador encontrar-se de férias ou licença no período de coleta dos dados. Destaca-se que, para este estudo, previamente, foi realizada a apresentação da pesquisa para a Secretaria de Estado de Saúde de Minas Gerais, a qual após a análise de sua viabilidade, autorizou o contato com os possíveis participantes. Neste sentido, vale ainda ressaltar que, os participantes foram contatados durante o desenvolvimento de suas atividades 
profissionais cotidianas, afim de que a coleta não representasse prejuízo à rotina de trabalho dos mesmos.

Sabe-se que por se tratar de um questionário, tal procedimento pode ocasionar risco mínimo, como exemplo, constrangimento ao participante ao falar de situações da sua vivência, por isso as respostas dos sujeitos entrevistados foram tratadas de forma anônima, sendo utilizadas somente com finalidade cientifica, isto significa que em nenhum momento do estudo foram divulgados os seus nomes.

Neste sentido, com o intuito de preservar a identidade dos respondentes, sem perder a riqueza expressa pelos textos, neste estudo adotaremos um pseudônimo alfanumérico para cada um dos participantes. Destaca-se que em consonância com a Resolução no 466 CNS - 2012, que dispõe sobre diretrizes éticas para a realização de pesquisas com a participação de seres humanos em território nacional, anteriormente à sua realização, o presente estudo foi encaminhado ao Comitê de Ética em Pesquisa da Universidade Federal de Juiz de Fora, sendo aprovado sob o parecer de número 1.520.068.

Para a operacionalização do processo de coleta de dados, optou-se pela utilização de um formulário on-line, cujo o processo de construção, iniciou-se após uma exaustiva revisão bibliográfica a respeito da temática relacionada à PNEPS, e da elaboração de um prospecto em formato World, do instrumento de coleta.

Para análise dos questionários foi utilizada a orientação metodológica da hermenêutica-dialética, tendo como referência os princípios do "método de interpretação de sentidos" proposto por Minayo. (2014), que preconiza a interpretação do contexto, das razões e da lógica das falas e das ações.

De acordo com a autora, Hermenêutica, se move nos seguintes termos: liberdade, necessidade, força, consciência histórica, significado, símbolo, intencionalidade, empatia como balizas do pensamento e a compreensão, um movimento abrangente e universal do pensamento humano (MINAYO, 2014).

Trata-se de uma categoria metodológica mais potente na atitude de investigação, uma vez que ela é considerada a disciplina básica que se ocupa da arte de compreender textos, que, neste estudo, seriam as entrevistas (MINAYO et al., 2013).

Compreender, por sua vez, implica a possibilidade de interpretar, de estabelecer relações e extrair conclusões em todas as direções, sem excluir as possibilidades de estar exposto a erros. Na lógica hermenêutica, a linguagem, nem 
sempre é considerada transparente, pois podemos chegar a um entendimento (nunca completo e nunca total) como a um não-entendimento (MINAYO, 2014).

Por isso, a ideia de alteridade e a noção de mal-entendido são possibilidades universais tanto no campo científico como no mundo da vida. A hermenêutica busca, portanto, esclarecer as condições sob as quais surge a fala. Ao entendermos a realidade que se expressa num texto, numa fala, também entendemos o outro (MINAYO, 2014).

Minayo (2014), destaca que a abordagem da hermenêutica busca diferenças e semelhanças entre o contexto dos autores e o contexto do investigador; supondo o compartilhamento entre o mundo observado e os sujeitos, buscando uma reflexão sobre o contexto histórico dos fatos e falas dos diferentes atores, de modo que esses se sintam contemplados.

Enquanto isso a dialética é a ciência e a arte do diálogo, da pergunta e da resposta, a qual busca na linguagem, nos signos e na cultura realizar a crítica sob os núcleos de sentido encontrados. O pensamento dialético cria instrumentos de crítica e compreensão com a finalidade de significar e valorizar as falas, relações e as ações" (MINAYO, 2014).

Dessa forma, quando articulamos a hermenêutica com a dialética, podemos valorizar as divergências e as complementaridades que existem entre elas, traçando assim um importante caminho para a fundamentação das pesquisas qualitativas, a partir da valorização das falas, das relações e das práticas. Vale ressaltar que, enquanto a hermenêutica enfatiza o consenso, a mediação e o acordo, a dialética se orienta para a diferença, o contraste, o dissenso e a crítica (MINAYO, 2014).

A partir dessa perspectiva, foram seguidos os seguintes passos: ordenação dos dados - através dos questionários, releitura do material e organização dos relatos; classificação dos dados - leitura compreensiva e repetida dos questionários, leitura de cada corpo com recorte de unidade de registro, identificação das regularidades e vivências singulares, por meio dos sentidos subjacentes às ideias descritas; análise final - elaboração das sínteses interpretativas, realizada com base nos objetivos da pesquisa e nos sentidos que emergem dos depoimentos. Desta forma, os textos coletados a partir dos questionários foram organizados em categorias de estudo a partir das ideias essenciais e analisados à luz da literatura (MINAYO, 2014). 
Salienta-se que o uso de ferramentas virtuais para a coleta de dados qualitativos, bem como a análise destes através da Hermenêutica Dialética caracteriza-se como uma proposta inovadora, e de significativa ousadia, porém que encontra respaldo cientifico, no proposto por Minayo (2014), onde a autora afirma que a Hermenêutica ocupa-se da arte de compreensão dos textos, bem como afirma, a amplitude do termo texto, conferindo-Ihe sentido amplo, e estendendo-lhe às biografias, narrativas, documentos, livros, artigos, dentre outros.

Deste modo, sob a prerrogativa da compreensão ampla do termo texto, utilizada pela autora, e da corroboração de Zanini (2007), ao afirmar que internet acessada mundialmente facilita as investigações com o uso do ambiente virtual, que aparece como uma tendência atual para a coleta de dados, possibilitando ao pesquisador ter acesso aos sujeitos de diferentes localidades, em um curto espaço de tempo, e a um baixo custo operacional, fundamenta-se o uso de uma ferramenta on-line para o desenvolvimento do presente estudo.

Torna-se relevante dizer, que embora a descrição do trajeto metodológico para a construção deste estudo e do formulário eletrônico, aparentemente pareça simplificada nesta descrição textual, ela é fruto do trabalho intenso e do processo de imersão da pesquisadora em todas as atividades pertinentes ao desenvolvimento da pesquisa ao longo do últimos 22 meses.

Para que o formulário eletrônico, entendido como um dos produtos da pesquisa emergisse, fez-se necessária, a reaproximação da pesquisadora com a temática, para a elaboração do projeto de pesquisa que atendesse as especificações do edital para a chamada 07/2017, do Programa de Pesquisa para o SUS (PPSUS)/FAPEMIG.

Após a aprovação do mesmo, pela agencia de fomento, foram realizadas discussões on-line entre a equipe, cujo o intuito fora a definição das atividades à serem desenvolvidas na etapa inicial da pesquisa, dando ênfase na definição do processo seletivo dos bolsistas e na forma de condução da revisão bibliográfica do estudo. Nesta foram estabelecidas ainda, quais seriam as atribuições de cada pesquisador, bem como reforçou-se sobre a importância do comprometimento de todos os membros.

Em seguida, realizou-se a seleção dos bolsistas BDTII-III, e BIC NACIONAL, através de dois processos seletivos públicos distintos, que como critério de seleção, visavam identificar a aproximação dos candidatos com a temática à ser 
desenvolvida. Finalizada a seleção dos bolsistas, deu-se início ao processo de treinamento dos candidatos aprovados, por meio de leituras direcionadas, fichamentos e discussões científicas relacionadas ao tema e ao método deste estudo, para que se aliassem-se às reflexões desenvolvidas pelo grupo de pesquisa.

Após esta etapa, a pesquisadora, articulou, uma parceria acadêmica, em busca de aprimoramento dos conhecimentos em informática, objetivando assim transformar o documento inicialmente em formato World, para um questionário no Google Forms.

A plataforma Google Forms, de acordo com a Google Inc. (2017), é uma ferramenta que oferece suporte para a criação de formulários personalizados de forma simples, que além de auxiliar a coleta de dados, facilita o processo de análise e interpretação dos mesmos, apresentando-os sob a forma organizada de tabelas e gráficos.

Corroborando Freitas (2004), Oliveira (2017) destaca a popularização do uso de formulários eletrônicos como ferramentas de pesquisa em diferentes áreas de conhecimento, tais como ciências sociais, educação, saúde, e economia na últimas décadas, e atribui o fenômeno às facilidades oferecidas pelos meios digitais, quando comparados aos métodos tradicionais de coleta de dados.

Para o autor, o uso dos formulários, diminuem os custos da pesquisa, pois permitem o acesso às plataformas sem cobrar qualquer valor por sua utilização, bem como minimizam e/ou eliminam os custos de deslocamento para a realização da coleta (FREITAS, 2004; OLIVEIRA, 2017).

Outra vantagem apontada pelo autor, é o sistema de armazenamento de dados "leve", ou seja, que não requer o uso de grandes espaços digitais, e "limpo", no qual o uso de papel é reduzido, uma vez que a própria plataforma funciona como um "HD (hard disc) virtual" acessível diretamente no navegador de internet, permitindo ao pesquisador acompanhar o andamento da pesquisa à medida que os dados vão sendo alimentados pelos participantes (FREITAS, 2004; OLIVEIRA, 2017).

Por fim, ressalta-se a validade de seu uso em pesquisas qualitativas, uma vez que, segundo Heidemann et al. (2010, p. 32) os diferentes estilos de perguntas disponibilizados pela plataforma, permitem ao pesquisador, realizar facilmente 0 "levantamentos de opiniões" dos participantes 
Sob estes pressupostos e com o auxílio do apoio técnico em informática, o formulário foi aperfeiçoado e subdivido em três seções com objetivos distintos, sendo elas: identificação dos participantes, compreensão e aplicação da temática ao objeto do estudo e análise do formulário.

A primeira seção destina-se à caracterização do perfil dos participantes, e visa coletar informações básicas à respeito deles, tais como o nome, a idade e o local de atuação profissional. Nela, estão ainda compreendidas, perguntas acerca da formação e qualificação profissional do sujeitos.

$\mathrm{Na}$ segunda seção, foram elaboradas oito perguntas a respeito da temática Educação Permanente em Saúde como um dispositivo de gestão. Neste momento, optou-se pelo formato de questionário semiestruturado, pois de acordo com Minayo (2014), nele o participante tem a possibilidade de discorrer livremente sobre o tema proposto, sem condições prefixadas pelo pesquisador. Ressalta-se que as perguntas desta etapa, objetivam, não somente analisar, quais os conceitos que os participantes possuem a respeito da temática, mas também, compreender como relacionam estes conhecimentos com sua prática cotidiana.

A terceira e última seção, destina-se à captação da avalição do participante a respeito do formulário eletrônico, como uma ferramenta na coleta de dados na pesquisa qualitativa. Nesta etapa, o profissional relatará como foi para ele, participar da pesquisa, e poderá sugerir alterações para o aperfeiçoamento do instrumento em futuras investigações.

Após a finalização da etapa de construção do formulário eletrônico, o mesmo foi apresentado para uma equipe de especialistas e estudantes da área de saúde, os quais apresentaram suas percepções e sugeriram aperfeiçoamentos, que foram analisados pela equipe de pesquisa e implementados de acordo com sua pertinência ao objeto e método do trabalho, resultando na inclusão de três novas perguntas ao formulário inicial.

Após a finalização da etapa de construção do formulário eletrônico, o mesmo foi apresentado para uma equipe de especialistas e estudantes da área de saúde, os quais apresentaram suas percepções e sugeriram aperfeiçoamentos, que foram analisados pela equipe de pesquisa de acordo com sua pertinência ao objeto e método do trabalho, resultando na inclusão de três novas perguntas ao formulário inicial. No quadro I abaixo está o modelo do questionário em sua primeira versão online. 
Quadro 1 - Questionário Online Versão 1

\begin{tabular}{l}
\multicolumn{1}{|c|}{ Questionário online } \\
\hline Pesquisa sobre a Educação Permanente como Dispositivo de Gestão do SUS \\
\hline \multicolumn{1}{|c|}{ Primeira Seção } \\
\hline I. Identificação dos participantes \\
Nome completo* \\
E-mail* \\
Sexo: Masculino ou Feminino * \\
Idade* \\
SRS/GRS* \\
II. Formação acadêmica \\
Área de formação da graduação: * \\
Ano de conclusão: * \\
Natureza da Instituição em que concluiu a graduação: Pública ou Privada* \\
Possui Pós-Graduação? Sim ou não* \\
Se sim, especifique: Lato senso ou Stricto senso \\
Caso se aplique, cite a especialidade e a data de formação. \\
Natureza da Instituição de conclusão da Pós-Graduação: Pública ou Privada \\
Aponte, pelo menos, 1 curso complementar que você já tenha feito, o qual esteja \\
correlacionado com a sua prática profissional: \\
Exemplo: Nome/Proposta do curso seguido da Data de Início e a Data de \\
conclusão. \\
Cite até três cursos. \\
Realizou nos últimos 3 ANOS, algum curso de atualização cuja temática relacione- \\
se com o processo de GESTÃO em seu ambiente de trabalho? Sim ou não* \\
Se sim, especifique: \\
Exemplo: Nome/Proposta do curso seguido da Data de Início e a Data de \\
conclusão. \\
III. Atuação Profissional \\
Setor de atuação na SRS/GRS: * \\
Função/Cargo em que atua: * \\
Tempo de atuação nesta função/cargo: * \\
Relate aqui experiências prévias que julgue relevantes para a sua carreira \\
profissional: \\
\hline
\end{tabular}




\section{Questionário}

1. O que você compreende por educação permanente em saúde? *

2. Em seu contexto de trabalho, quais ações de educação permanente em saúde são realizadas? Para quem essas ações são direcionadas? *

3. Quais são os principais desafios que você identifica para a implementação e consolidação da Educação Permanente em seu ambiente de trabalho? *

4 Quais são os principais desafios que você identifica para a implementação e consolidação da Educação Permanente nos territórios e nos municípios de sua abrangência? *

\section{5. "O que você compreende como processo de gestão em saúde?" *}

6. "Como este conceito se aplica à sua realidade cotidiana de trabalho?"*

7."Você acredita que sua formação profissional, contribui para à aplicabilidade dos conceitos acima, em sua prática cotidiana?"*

8. Em seu trabalho, você desenvolve ações direcionadas aos profissionais da Atenção Primária da Saúde? Sim ou não*

9. Se sim, quais seriam?

10. Na sua opinião, como a Educação Permanente, pode contribuir enquanto dispositivo de gestão do SUS? *

11. Caso ache necessário, use livremente este espaço, para abordar algum assunto ou situação relacionada à temática desta pesquisa que não tenha sido retratado nas perguntas acima.

\section{Terceira Seção}

\section{Avaliação do Instrumento}

Para você, como foi responder este instrumento on-line? *

Você acredita que instrumentos como este, podem facilitar o desenvolvimento de pesquisas científicas realizadas em localidades variadas? *

Quais as vantagens e as limitações, identificadas por você, neste instrumento? *

Você incluiria alguma questão neste formulário? Se sim, especifique qual. * 


\section{Caro(a) participante, desde já agradecemos a sua colaboração nesta pesquisa!}

Quaisquer dúvidas e/ou sugestões sobre tal trabalho, fique à vontade para entrar em contato através do e-mail: projetomestradoenf2018@gmail.com

\section{*Perguntas de resposta obrigatória.}

Fonte: Projeto APQ 04203/17 PPSUS/FAPEMIG (2017)

$\mathrm{Na}$ sequência o formulário foi enviado para um pequeno grupo de participantes, e a partir das respostas obtidas, pode-se verificar a pertinência e a clareza das questões propostas através de um pré-teste desenvolvido a partir de um Trabalho de Conclusão de Curso (TCC) de Graduação em Enfermagem, desta mesma escola (SILVA, 2018).

No TCC (SILVA, 2018) o pré-teste avaliou as discrepâncias, ambiguidades e formulações equivocadas das questões nas seguintes dimensões: fidedignidade, operatividade e validade.

Para Lakatos e Marconi (2010), autoras que balizaram o TCC (SILVA, 2018) as dimensões necessárias ao pré-teste são definidas como:

- Fidedignidade: obtenção dos mesmos resultados independente do aplicador;

- Operatividade: busca por vocabulário acessível e significado claro;

- Validade: que tem valor ou legitimidade, significa dizer se os dados são necessários à pesquisa. Além de permitir a estimativa sobre os futuros resultados da mesma (LAKATOS E MARCONI, 2010).

Vale destacar, que o quesito validade é uma parte importante desse pré-teste, pois analisou se as respostas obtidas tinham potencial para atender aos objetivos da pesquisa.

Os resultados do pré-teste sinalizaram que haviam algumas discrepâncias, ambiguidades e formulações equivocadas nas seguintes questões da segunda seção, subdivisão IV - Questionário (OLIVEIRA SILVA, 2018). Nesta perspectiva, questões foram alteradas para atenderem os objetivos da pesquisa, sendo elas: 
A questão cinco: "O que você compreende como processo de gestão em saúde?"

Foi alterada para "O que você compreende por gestão em saúde?", pois foi observado que a presença da palavra "processo" modificou o objetivo da questão, principalmente nos elementos de validade, que versa se as respostas tem potencial de servir aos objetivos da pesquisa e operatividade que é a busca por significado claro nas respostas (LAKATOS E MARCONI, 2010),

A questão seis: "Como este conceito se aplica à sua realidade cotidiana de trabalho?"

Foi alterada para: "Como a gestão em saúde se aplica em sua realidade cotidiana de trabalho?", pois as respostas não abordaram de forma completa o questionamento da pergunta diminuindo sua validade.

A questão sete: "Você acredita que sua formação profissional, contribui para à aplicabilidade dos conceitos acima, em sua prática cotidiana?"

Foi alterada para: "Como sua formação profissional, contribui para à aplicabilidade dos conceitos acima, em sua prática cotidiana?”, por entender que o texto anterior gerava dúvidas para os respondentes entre respostas de teor afirmativa ou negativas e descritivas.

Por fim, todo o material foi encaminhado para a avaliação da Diretoria de Desenvolvimento de Pessoas da Superintendência de Gestão de Pessoas das Secretarias de Estado de Minas Gerais, a qual depois de sugerir algumas alterações relativas à formatação do documento autorizou o disparo da versão final do instrumento para o e-mail dos participantes.

O quadro II mostra a versão final do formulário online que foi enviado para os profissionais de saúde da SRS/MG que atuam em projetos e programas na atenção primária em saúde nos municípios mineiros. 
Quadro 2 - Questionário Online Versão Final

\begin{tabular}{l}
\multicolumn{1}{|c|}{ Questionário online } \\
\hline \multicolumn{1}{|c|}{ Primeira Seção } \\
\hline Pesquisa sobre a Educação Permanente como Dispositivo de Gestão do SUS \\
\hline I. Identificação dos participantes \\
Nome completo* \\
E-mail* \\
Sexo: Masculino ou Feminino * \\
Idade* \\
SRS/GRS* \\
II. Formação acadêmica \\
Área de formação da graduação: * \\
Ano de conclusão: * \\
Natureza da Instituição em que concluiu a graduação: Pública ou Privada* \\
Possui Pós-Graduação? Sim ou não* \\
Se sim, especifique: Lato senso ou Stricto senso \\
Caso se aplique, cite a especialidade e a data de formação. \\
Natureza da Instituição de conclusão da Pós-Graduação: Pública ou Privada \\
Aponte, pelo menos, 1 curso complementar que você já tenha feito, o qual esteja \\
correlacionado com a sua prática profissional: \\
Exemplo: Nome/Proposta do curso seguido da Data de Início e a Data de \\
conclusão. \\
Cite até três cursos. \\
Realizou nos últimos 3 ANOS, algum curso de atualização cuja temática relacione- \\
III. Atuação Profissional \\
Setor de atuação na SRS/GRS: * processo de GESTÃO em seu ambiente de trabalho? Sim ou não* \\
Fe sim, especifique: \\
Exemplo: Nome/Proposta do curso seguido da Data de Início e a Data de \\
Tempo de atuação nesta função/cargo: * \\
Relate aqui experiências prévias que julgue relevantes para a sua carreira \\
profissional: \\
\hline IV. Questionário \\
1. O que você compreende por educação permanente em saúde? *
\end{tabular}


2. Em seu contexto de trabalho, quais ações de educação permanente em saúde são realizadas? Para quem essas ações são direcionadas? *

3. Quais são os principais desafios que você identifica para a implementação e consolidação da Educação Permanente em seu ambiente de trabalho? *

4. Quais são os principais desafios que você identifica para a implementação e consolidação da Educação Permanente nos territórios e nos municípios de sua abrangência? *

5.O que você compreende por gestão em saúde? *

6. Como a gestão em saúde se aplica em sua realidade cotidiana de trabalho? *

7. Como sua formação profissional, contribui para a aplicabilidade dos conceitos acima, em sua prática cotidiana? *

8. Em seu trabalho, você desenvolve ações direcionadas aos profissionais da Atenção Primária da Saúde? Sim ou não*

9. Se sim, quais seriam?

10. Na sua opinião, como a Educação Permanente, pode contribuir enquanto dispositivo de gestão do SUS? *

11. Caso ache necessário, use livremente este espaço, para abordar algum assunto ou situação relacionada à temática desta pesquisa que não tenha sido retratado nas perguntas acima.

\section{Avaliação do Instrumento}

\section{Terceira Seção}

Para você, como foi responder este instrumento on-line? *

Você acredita que instrumentos como este, podem facilitar o desenvolvimento de pesquisas científicas realizadas em localidades variadas? *

Quais as vantagens e as limitações, identificadas por você, neste instrumento? *

Você incluiria alguma questão neste formulário? Se sim, especifique qual. *

Caro(a) participante, desde já agradecemos a sua colaboração nesta pesquisa!

Quaisquer dúvidas e/ou sugestões sobre tal trabalho, fique à vontade para entrar 
em contato através do e-mail: projetomestradoenf2018@gmail.com

*Perguntas de resposta obrigatória

Fonte: Projeto APQ 04203/17 PPSUS/FAPEMIG (2017) 


\section{RESULTADOS}

Dos 151 formulários eletrônicos enviados para os profissionais das GRSs e SRSs, obteve-se retorno de 61,5\% (41 formulários), através dos quais foi percebido no trigésimo primeiro, a saturação dos dados. Para a constatação do adensamento teórico, foram avaliados além do ponto de saturação, mais 10 formulários, os quais confirmaram a reincidência das informações já coletadas.

Dos 28 municípios contatados, 18 retornaram formulários. O Perfil apresentou-se predominantemente feminino $(77,5 \%)$, com idade compreendida entre 27 e 61 anos, e com tempo de atuação nas atividades de gestão das SRS's e GRS's entre 01 e 30 anos.

Dos 31 respondentes, 16 possuem formação superior em instituições públicas de ensino, e 15 em instituições privadas, sendo estes 18 enfermeiros; 03 odontólogos; 02 assistentes sociais; 02 nutricionistas; 01 psicólogo; 01 pedagogo; 01 biólogo; 01 economista; 01 médico veterinário e 01 bacharel em letras, dos quais 04 afirmam possuir pós graduação Stricto Sensu, 19 Lato Sensu e 1 Stricto Sensu e Lato Sensu. 07 participantes não possuem nenhum tipo de pós graduação.

Para facilitar a organização das informações emergidas do corpus, foi elaborado o quadro a seguir (QUADRO III), o qual traz a apresentação das categorias e núcleos de sentido encontrados.

Quadro 3 - Apresentação das Categorias e Núcleos de Sentido

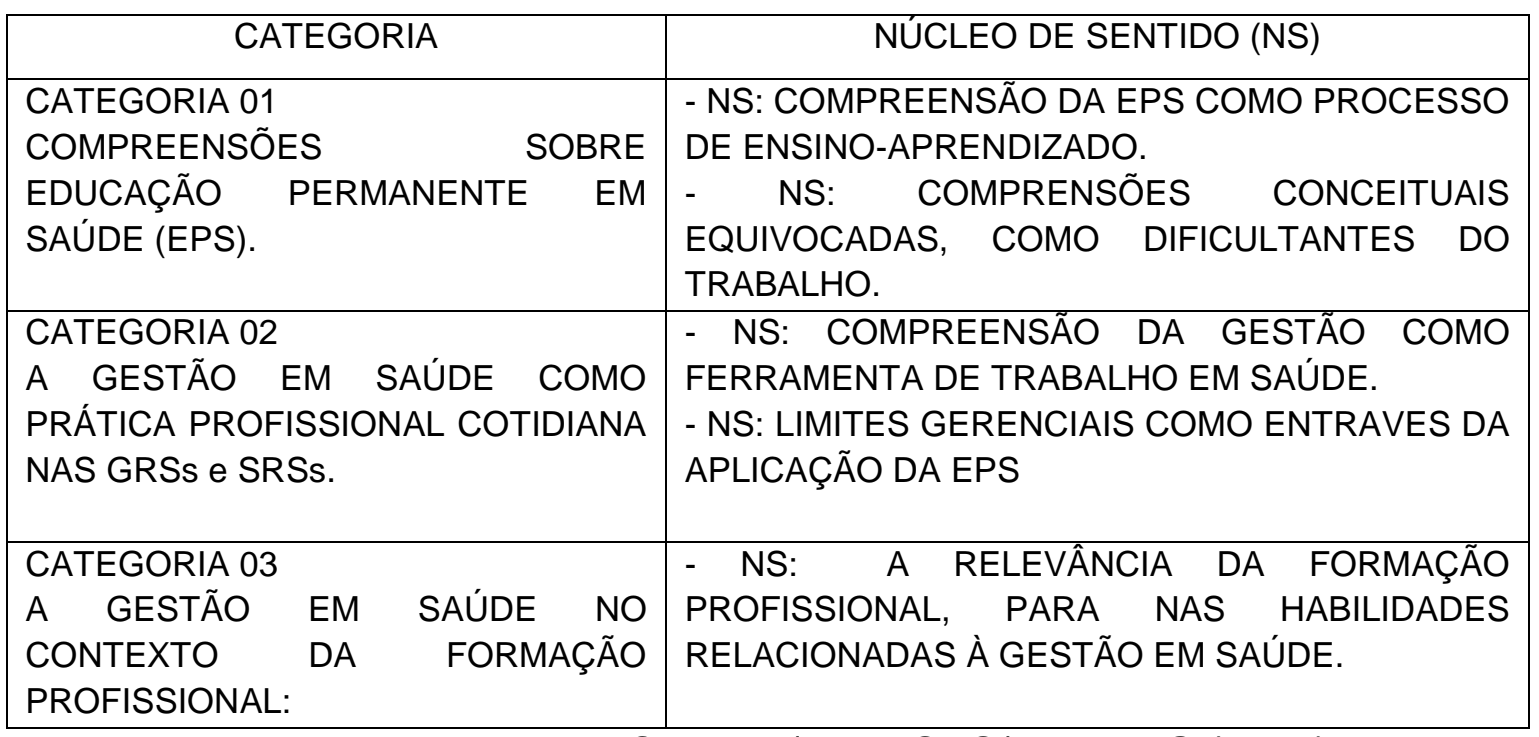

Fonte: Projeto APQ 04203/17 PPSUS/FAPEMIG (2017) 


\subsection{CATEGORIA 01: COMPREENSÕES SOBRE EDUCAÇÃO PERMANENTE EM SAÚDE (EPS)}

\subsubsection{NS: Compreensão da EPS como processo de ensino-aprendizado}

Para os participantes deste estudo, a EPS é compreendida como processo de ensino-aprendizado, que emerge a partir das vivências individuais e de trabalho dos indivíduos. Tal percepção pode ser evidenciada através das unidades de sentido abaixo:

"Educação permanente em saúde é um tipo de prática de ensino e aprendizagem, pautada no contexto do serviço, que tem como objetivo identificar instrumentos e formas de enfrentamento dos problemas existentes na prática profissional [...]"

"Processo ensino aprendizagem que considera as vivências cotidianas do profissional em serviço[...]".

"O processo de ensino-aprendizagem é relacionado à atuação no campo da saúde, ocorrendo de modo planejado a partir da avaliação das necessidades e potencialidades [...]"

\subsubsection{NS: Compreensões conceituais equivocadas, como dificultantes do trabalho}

Nas unidades de sentido a seguir, os participantes discorrem sobre a relevância das ações de educativas por eles desenvolvidas, descrevendo-as equivocadamente como ações de EPS:

"[...] são ações do tipo oficinas, encontros e que as vezes acontecem até mesmo através telefonemas, whatssap e e-mail [...]"

"Realizamos ações de capacitações e atualização dos profissionais municipais, como por exemplo treinamento de Agentes Comunitários de Saúde, Equipes de Saúde da Família, NASF's, sistema de informação da Atenção Básica, etc [...]"

"Desenvolvemos ações de educação continuada com os municípios da jurisdição da SRS P(protegido). Reuniões técnicas, oficinas, cursos e capacitações direcionadas aos profissionais técnicos de saúde dos municípios [...]". 


\subsection{CATEGORIA 02: A GESTÃO EM SAÚDE COMO PRÁTICA PROFISSIONAL COTIDIANA NAS GRSs e SRSs:}

\subsubsection{NS: Compreensão da gestão como ferramenta de trabalho em saúde}

Através das unidades de sentido expostas abaixo, podemos compreender como os participantes concebem e aplicam o conceito de gestão em saúde em suas atividades cotidianas:

" Gestão em saúde diz respeito a forma de condução dos serviços de saúde, compreendendo sua complexidade e a dinâmica dos processos de trabalho, utilizando ferramentas de planejamento, monitoramento e avaliação de ações, indicadores[...]".

"A gestão consiste em coordenar os processos de trabalho e da organização do sistema público de saúde com conhecimentos para a aplicação das políticas públicas e relações com os usuários do SUS[...]".

" É a administração por um determinado ente, que por meio de articulação entre setores e pessoas, também aquisição de bens e serviços, possui o objetivo de proporcionar ou garantir o acesso à saúde para a população[...]".

"Ações gerenciais no âmbito da saúde, planejamento nos níveis municipal, regional, estadual, federal. Pensar políticas públicas em saúde, executar políticas já existentes. Trabalhar com planejamento orçamentário e financeiro[...]".

"É a capacidade de direcionar recursos humanos e materiais em direção aos objetivos da instituição de saúde, maximizando os resultados, melhorando a qualidade da assistência prestada e reduzindo custos desnecessários [...]".

\subsubsection{NS: Limites gerenciais como entraves da aplicação da EPS}

A seguir, as unidades de sentido, evidenciam os principais limites gerenciais apontadas pelos participantes como fatores dificultadores para a implementação e efetivação da EPS, nos cenários do estudo:

\footnotetext{
"Disponibilização de recursos financeiros e materiais[...]"

" Dificuldades de criar e manter uma agenda de EP em meio as demandas [...]"

" Baixa visibilidade da EPS enquanto potência de mudança no território [...]"

" Falta de percepção da gestão local da importância da EPS [...]"
} 
"Planejamento e efetivação por parte do nível central de uma Política de EPS [...]"

" Falta de Recurso Humano, falta de planejamento, alta rotatividade de gestores [...]"

"Instabilidade dos cargos, pouca interesse dos profissionais [...]"

\subsection{CATEGORIA 03: A GESTÃO EM SAÚDE NO CONTEXTO DA FORMAÇÃO PROFISSIONAL}

\subsubsection{NS: a relevância da formação profissional, para nas habilidades relacionadas à gestão em saúde}

Através das unidades destacadas neste núcleo, pode-se perceber o valor atribuído pelos participantes ao conhecimento gerencial, construído durante a formação profissional:

"A minha formação profissional desde a finalização da graduação tem contribuído na gestão em saúde nos momentos de encontros com os atores envolvidos nos vários momentos, desde a aplicabilidade de alguns programas até a negociação de situações que envolvam a realização de novas ações ou a melhoria das já existentes [...]"

"Contribui bastante na compreensão da gestão a partir do olhar assistencial. Minha formação na graduação foi mais focada na administração e assistência de enfermagem do que nas questões de saúde pública - hoje o currículo do curso já mudou, mas a prática profissional é que me atualiza e me agrega mais conhecimento [...]"

"A formação como enfermeira e a experiência em equipe de ESF, permite ter uma noção maior da realidade, das dificuldades de execução das ações na assistência direta e de certa forma facilita a compreensão das necessidades e aplicação das ações de educação permanente, de capacitação dos profissionais. Além disso, permite uma reflexão mais crítica dessas necessidades, uma vez que muitos conhecimentos são inerentes ao processo de formação profissional e outras demandas são originadas da prática assistencial e requerem aperfeiçoamento constante [...]" 


\section{DISCUSSÃO}

5.1 CATEGORIA 01: Compreensões sobre educação permanente em saúde (EPS)

\subsubsection{NS: Compreensão da EPS como processo de ensino-aprendizado}

Os resultados obtidos através dos formulários, subsidiaram a construção das categorias e núcleos de sentido anteriormente apresentados, os quais, traduzem em formato sintético os achados da pesquisa em questão.

Através da análise das categorias, núcleos e unidades de sentido anteriormente apresentados, evidencia-se que para os participantes deste estudo, a EPS é compreendida como um processo de ensino-aprendizado, que emerge a partir das vivências individuais e de trabalho dos indivíduos.

Tal percepção converge ao proposto por Goês (1991), o qual afirma que o processo ensino aprendizado extrapola a lógica da reprodução vazia de conhecimentos ou experiências, devendo ser compreendido como a interação dialógica entre os planos inter e intra-psíquicos dos indivíduos. Entretanto, para que se possa verdadeiramente desvelar os sentidos deste processo, expressos através das falas dos participantes, faz-se necessário o aprofundamento conceitual sobre a temática.

Historicamente, a educação estabeleceu-se como um modelo pedagógico de reprodução e legitimação das hierarquias, sendo por muitas décadas compreendida como um instrumento de adaptação social, cujo o principal propósito visava mudar os comportamentos, crenças e atitudes dos indivíduos, mantendo-os sob normas estabelecidas pela sociedade e pela ordem biomédica (MELO, 1989).

Todavia, frente ao desafio de uma prática educativa inovadora, capaz de ir ao encontro das necessidades individuais dos aprendizes e das dificuldades postas pelas demandas sociais na atualidade, educadores e estudiosos da pedagogia inquietam-se em propor modelos pedagógicos que valorizem as relações interpessoais, tendo na EP, um dispositivo de superação das obsoletas e massivas práticas de reprodução alienada de conteúdo.

Para Vygotsky (2010), a construção de um novo modelo educacional, cuja a centralidade esteja voltada para as necessidades do sujeito, perpassa pela compreensão do processo ensino-aprendizagem como uma experiência sociocultural entre os indivíduos, que se dá através da contextualização, e da 
problematização, associadas aos processos de repetição, memorização e transmissão, os quais apesar de parecerem contraditórios, se complementam, gerando como produto final a internalização, e consequentemente, a aprendizagem.

Para o autor, à medida que se possibilita ao aprendiz, a construção uma "zona coletiva de desenvolvimento proximal", juntamente à seus pares, tende-se à reafirmação das habilidade que os indivíduos já possuem, e amplia-se o potencial de aprendizado e crescimento futuro dos mesmos.

Freire (1983), corrobora o proposto por Vygotsky, salientando que a significação do aprendizado pelos indivíduos pode ter caráter individual e/ou coletivo, de acordo com os interesses para qual é proposta, exigindo desta forma, mediações significativas para que ocorra.

No campo da saúde, para que o processo ensino aprendizado, ocorra de forma eficaz, as mediações são indispensáveis, visto que, somente o conhecimento prévio e as experiências individuais dos sujeitos, não formam isoladamente, um constructo significativo para o coletivo, necessitando assim, que os novos conhecimentos sejam socializados, problematizados, correlacionados, e sintetizados para que se tornem propriedade comum entre os trabalhadores, passíveis de internalização por todo o grupo (PINO,1991).

Para Paim (1996), as práticas educativas, não devem ser compreendidas apenas como uma mero reflexo das práticas sociais, mas à medida que transformam a realidade dos indivíduos e das coletividades, são por si só, uma produção social.

Sob este pressuposto, deve-se continuamente estimular que as instituições de saúde, transformem-se, e estabeleçam processos educativos cotidianos que, dentre outros atributos, valorizem as relações interpessoais existentes no processo de trabalho, em prol da qualidade, e da eficiência da assistência.

Entretanto o rompimento com as antigas amarras do processo educativo socialmente estabelecido traz consigo inúmeros desafios, os quais perpassam desde necessidade latente de se repensar as relações humanas pertinentes ao processo, até às dificuldades estruturais e burocráticas do sistema, tais desafios foram fortemente marcados pelos participantes deste estudo e serão discutidos nas próximas categorias. 


\subsubsection{NS: Compreensões conceituais equivocadas, como dificultantes do processo de trabalho}

Pode-se perceber, através do corpus emergido das respostas dos participantes, dificuldades na dissociação entre os termos "Educação Continuada" e "Educação Permanente", embora estes não se apresentem de maneira oposta, necessitam ser compreendidos a partir de suas especificidades.

Ressalta-se que para este estudo, não foi aplicado juízo de valor sobre as compreensões dos participantes, e desta forma as respostas obtidas, não foram classificadas como certas ou erradas, mas como aproximações ou distanciamentos do proposto pela Política Nacional de Educação Permanente em Saúde, a qual descreve

Através das análises pode-se compreender que embora os profissionais investigados, compreendem a relevância e a necessidade do desenvolvimento de atividades educativas aplicadas ao cotidiano de trabalho em saúde, todavia não delimitam com clareza, se as ações por eles desenvolvidas correspondem à práticas de "Educação Continuada" e "Educação Permanente".

Sardinha (2013), destaca que a dificuldade de delimitação conceitual encontrada neste estudo, pode ser percebida também em outras publicações, e guarda relação com a ausência de uma unidade entre os autores ao dissertarem sobre a temática. Para o autor, nas várias literaturas disponíveis, cada autor discorre sobre o processo de educação no trabalho de acordo com suas reflexões, podendo ou não, ter a PNEPS como fonte primária, a qual descreve a Educação Permanente em Saúde como:

"Processo de aprendizagem no trabalho, onde o aprender e o ensinar se incorporam ao cotidiano das organizações e ao trabalho. A EPS se baseia na aprendizagem significativa e na possibilidade de transformar as práticas profissionais e acontece no cotidiano do trabalho" (BRASIL, 2004a).

Enquanto a Educação Continuada, é delimitada pelo Ministério da Saúde, como: 
"Conjunto de práticas que contemplam atividades de período definido para execução e que utiliza, em sua maior parte, os pressupostos da metodologia de ensino tradicional. Relaciona-se às atividades educacionais que visam promover a aquisição sequencial e acumulativa de informações técnicocientíficas pelo trabalhador, por meio de práticas de escolarização de caráter formal, bem como de experiências no campo da atuação profissional, no âmbito institucional ou externo a ele" (BRASIL, 2018).

Sardinha (2013), afirma ainda que enquanto a maioria das literaturas definem a Educação Continuada concerne à Educação Permanente, tal como o posto pela PNEPS, alguns poucos insistem em reafirmar que ambas tratam-se do mesmo processo, pois objetivam a qualificação dos trabalhadores da saúde. A ausência de um consenso na literatura sobre os conceitos de Educação Permanente em Saúde e Educação Continuada em Saúde, corroboram os achados desta investigação que demostram na prática, o descrito pelo autor supracitado.

Para Farah (2003) os processos de educação para profissionais de saúde modificam-se e evoluem de acordo com o momento sócio-econômico-político vivenciado no país, e desta forma conceitos que outrora foram utilizados como sinônimos, devem na atualidade serem compreendidos de forma complementar, tendo sua utilização adaptada à cada realidade em que será empregada.

Outra possível compreensão, para a ausência de clareza evidenciada nas respostas, diz respeito às possíveis lacunas na formação destes profissionais, todavia, tal discussão será aprofundada na categoria 03 deste estudo. 


\subsection{CATEGORIA 02: A GESTÃO EM SAÚDE COMO PRÁTICA PROFISSIONAL COTIDIANA NAS GRSs e SRSs}

\subsubsection{NS: Compreensão da gestão como ferramenta de trabalho em saúde}

Através das respostas obtidas pelos formulários eletrônicos, evidenciou-se neste estudo, que os participantes compreendem e validam a gestão, como uma importante ferramenta no processo de trabalho em saúde.

Tais achados, puderam ser constatados a partir das revelações sobre como estes compreendem a gestão, e sua aplicação ao trabalho cotidiano em saúde, as quais aproximam-se do proposto conceitual de Matos (2006) e Lorenzetti (2014).

Para os autores supracitados, a gestão/administração, pode ser definida como o conhecimento e/ou tecnologia aplicada no manejo das organizações de saúde, envolvendo a gerência das instituições públicas, privadas, hospitais, laboratórios, clínicas e demais serviços de saúde.

Ainda de acordo com Lorenzetti (2014), a gestão quando aplicada ao campo da saúde, pode ainda ser compreendida como uma estratégia de articulação entre as diferentes esferas do SUS, em prol de uma assistência qualificada, equânime, integral e universal.

Através dos textos emergidos do corpus, também foi possível perceber que os participantes compreendem a relevância da gestão como ferramenta facilitadora do trabalho em saúde, pois ao serem interpelados sobre a temática, a destacaram como uma estratégia de alcance de metas, redução de desigualdades e aprimoramento do Sistema Único de Saúde, indo desta forma, ao encontro da PNEP e de autores como Campos (2009) Silva; Flausino e Gondim (2017).

Segundo Silva; Flausino e Gondim (2017), nos espaços de saúde a gestão tem por objetivo organizar os processos de trabalho, assegurar as condições para implementação da atenção à saúde de acordo com as necessidades da população, e contribuir com a qualidade assistencial.

A Portaria № 198/2004, a qual instituí a Política de EPS, descreve a gestão, como um do componentes do já mencionado quadrilátero da EPS, a qual busca democratizar os espaços de trabalho ao articular as habilidades gerenciais às especificidades do campo da saúde (BRASIL, 2004b).

No contexto do SUS, para que as políticas e programas de saúde sejam realmente efetivas, suas ações devem abranger toda a rede de serviços e esferas 
administrativas do sistema, dentre eles as SRS's e GRS's (CAMPOS, 2009), e neste sentido a EPS pode revelar-se como um importante dispositivo gerencial.

Embora os achados, deste NS, revelam-se de forma bastante positiva, permitindo-nos inferir que ao compreenderem as concepções de gestão, como ferramentas do processo de trabalho, e ao destacarem sua relevância para a efetividade das ações de saúde, os participantes encontram-se receptivos à implementa-la em seus cotidianos, deve-se reconhecer que o processo gerencial em saúde brasileiro, encontra-se ainda repletos de desafios.

Para Lorenzetti (2014), o mais complexo dos desafios da gestão aplicada ao campo da saúde na atualidade, está em construir ou reconstruir para as próximas gerações serviços de saúde que venham a ser efetivamente centrados nas pessoas, grupos, comunidades e suas demandas de saúde.

Desta forma, lançar mão de estratégias tais como a EPS, que possam contribuir com o fortalecimento da gestão do SUS, e com a qualidade da assistência por ele ofertada, caracteriza-se como uma missão para os gestores.

\subsubsection{NS: Limites gerenciais como entraves da aplicação da EPS}

Embora tenham descrito a relevância dos processos gerenciais como ferramentas de singular importância no cotidiano de trabalho em saúde, os participantes reconhecem que existem em seus cenários de atuação, dificuldades gerenciais para a aplicação efetiva da EPS.

Dentre os principais entraves evidenciados pelos participantes, destaca-se a falta de adesão dos gestores e trabalhadores às ações de EPS, justificada pela falta de incentivo e visibilidade às ações já implementadas. Sob à ótica destes trabalhadores, é apontado um distanciamento entre a PNEPS e a realidade de trabalho por eles vivenciada nas SRS's e GRS's.

Para Peduzzi et al. (2009) e Pinheiro (2018), tal distanciamento advém das dificuldades das esferas superiores de gestão do SUS, de alicerçar o desenvolvimento da PNEPS, articulando a formação, trabalho e a gestão de forma integrada às reais necessidades do atores envolvidos.

Em acordo ao descrito por D’Ávila et al.(2014), os participantes destacam também, que a escassez de recursos financeiros, materiais e estruturais, são fatores desmotivantes para os gestores e trabalhadores das GRS's e SRS's estudadas, 
caracterizando-se como limitadores das ações de EPS em suas realidades de trabalhos. Tais achados também puderam ser evidenciados em estudos anteriores, tais como os de Cardoso (2012), Lorenzetti (2014) e Pinheiro (2018), realizados em cenários semelhantes ao deste estudo, reforçando assim a relevância de reflexão sobre a temática.

O apontamento de tal realidade, condiz com o proposto por Alves (2007), que ressalta a necessidade da superação da burocracia e da lentidão na liberação dos recursos, atualmente centralizados no Ministério da Saúde, como um grande desafio para a efetivação das estratégias de EPS.

Tais dificuldades associam-se ainda, à alta rotatividade dos profissionais atuantes nestes espaços, fator que se caracteriza como um impedimento para o fortalecimento dos vínculos profissionais e para a implementação de estratégias de médio e longo prazo (PINHEIRO, 2018)

Ainda na vertente dos recursos humanos, é destacado pelos participantes, que o reduzido número de trabalhadores nestas instâncias, não faz jus ao grande volume de atividades que desenvolvem, impedindo-os de atenderem as demandas específicas dos serviços e consequentemente de operacionalizarem a EPS como uma estratégia de gestão, justificando assim, a falta de tempo, como mais um dos entraves para a consolidação da EPS.

Neste sentido, as falas dos participantes são endossadas por Silva (2017), que destaca a readequação do quadro profissional, às necessidades do serviços, como um dos grandes desafios para o sucesso das ações de EPS.

Ao considerarmos as principais dificuldades gerenciais destacadas pelos participantes deste estudo sob a luz da literatura cientifica, pode-se notar, que os achados repetem-se em diferentes estudos, realizados nos mais variados cenários do SUS, permitindo-nos assim inferir, que tais entraves necessitem de intervenção à nível macro de gestão.

Desta forma, para que tais dificuldades sejam verdadeiramente superadas, em especial, nas SRS's e GRS's, faz-se necessário um alto investimento não somente em recursos financeiros e materiais, mas principalmente em estratégias de fortalecimento da Política Nacional de Educação Permanente em Saúde e das relações interpessoais existentes nos espaços de gestão do SUS. 


\subsection{CATEGORIA 03: A GESTÃO EM SAÚDE NO CONTEXTO DA FORMAÇÃO PROFISSIONAL}

\subsubsection{NS: A relevância da formação profissional, para a construção de habilidades relacionadas à gestão em saúde}

Desde a implantação do SUS em 1988, o modelo brasileiro de formação em saúde, vem transformando-se significativamente, e os currículos dos cursos da saúde que até então priorizavam as ações curativas, tendo por base o modelo flexneriano, biomédico e hospitalocentrico, passaram à comtemplar o desenvolvimento de ações preventivas, educativas e administrativas sob a luz dos princípios de integralidade, equidade e universalidade (RIBEIRO, 2002).

De acordo com Silva (2005), os conteúdos relacionados ao saberes administrativos lecionados nos cursos de graduação em saúde até o século $X X$, demonstravam-se obsoletos e fragmentados, apontando para a latente necessidade de se repensar, o modelo formativo posto.

Desta forma, no ano 2000, em resposta às necessidades emergidas do novo cenário de saúde pública brasileira, realizou-se a XI Conferência Nacional de Saúde, na qual, através da Política Nacional de Recursos Humanos para o SUS, foram formuladas propostas para a formação dos profissionais.

Tais propostas tinham por objetivo incentivar a formação de gestores, garantir a realização de programas de capacitação de recursos humanos, bem como a elaboração de projetos técnicos e de informação. (CECCIM; ARMANI; ROCHA, 2002).

Ainda na busca do aprimoramento dos processos formativos em saúde, em 2001, foram elaboradas as Diretrizes Curriculares Nacionais (DCNs) dos cursos da saúde, as quais objetivam formar profissionais que sejam "capazes de atuar com qualidade, eficiência e resolutividade, no Sistema Único de Saúde (BRASIL 2001).

Dentro da perspectiva de assegurar a flexibilidade, a diversidade e a qualidade da formação oferecida aos estudantes, as diretrizes estimulam 0 abandono das antigas concepções de grades curriculares; a superação do modelo transmissivo de conhecimento, almejando garantir uma formação sólida, capaz de preparar o futuro graduado para enfrentar os desafios das rápidas transformações da sociedade, do mercado de trabalho e das condições de exercício profissional (BRASIL, 2001). 
Os achados do estudo, refirmam o proposto pelos autores supracitados, à medida que os participantes destacam a relevância do aprendizado de habilidades relacionadas à gestão durante a graduação e pós graduação. Para os mesmos, a prática profissional que desenvolvem cotidianamente na atualidade, reflete os conhecimentos adquiridos ao longo do ensino superior.

Baraldi (2014) corrobora os achados do estudo, afirmando que o contato, desde o ambiente acadêmico, com as reais necessidades e carências da população assistida desperta no futuro profissional sua capacidade de questionamento e transformação do meio por intermédio de suas ações (BARALDI, 2014).

Batista (2013), endossa a discussão apontando que os conhecimentos adquiridos ao longo dos anos de graduação e seus subsequentes, impactam diretamente na adesão dos gestores aos programas de saúde, propondo assim que os conhecimentos do campo da gestão sejam inseridos desde os anos iniciais da formação dos profissionais de saúde.

Reconhece-se entretanto, que apesar dos esforços públicos, das políticas e das diretrizes, que embasadas por conhecimentos científicos, ressaltam sobre a relevância do contato precoce dos discentes com os saberes do campo da gestão, esta ainda não é uma realidade para todos os estudantes.

Através das sínteses das respostas obtidas neste estudo, pudemos perceber que o profissionais que não se aproximaram destes saberes ao longo da graduação e pós graduação, demostraram maiores dificuldades em expressar a definição do conceito GESTÃO, bem como sua aplicação em seu cotidiano de trabalho.

Tal inferência, nos permite reafirmar que para a superação das dificuldades evidenciadas pelos participantes nas categorias anteriores, bem como para a construção de habilidades relacionadas à gestão em saúde, faz necessário não somente a formulação de novas diretrizes e/ou políticas, mas se repensar o modelo formação dos profissionais responsáveis por sua condução nas mais variadas frentes de atuação do SUS. 


\section{CONSIDERAÇÕES FINAIS}

Orientando-se para a melhoria da qualidade, do acesso e da humanização na prestação de serviços de saúde, bem como para o fortalecimento dos processos de gestão político-institucional do SUS, no âmbito federal, estadual e municipal, a EPS caracteriza-se como uma proposta inovadora de gestão, a qual visa compreender a dinamicidade e complexidade do campo da saúde.

Trata de um processo de ensino-aprendizado, no qual podem ser percebidos as fragilidades e potencialidades de um dado processo de trabalho, através da incorporação do ensino, da atenção à saúde, da gestão do sistema e da participação do controle social, objetivando-se a qualificação e aperfeiçoamento das práxis desenvolvidas em vários níveis do sistema de saúde.

Nesta investigação, adotamos a definição para Educação Permanente em Saúde (EPS), proposta pela Política Nacional de Educação Permanente em Saúde (PNEPS), que a caracteriza como uma proposta ético-político-pedagógica que ambiciona transformar e qualificar a atenção à saúde, seus processos formativos, suas práticas de educação em saúde, bem como incentivar a organização das ações e dos serviços numa perspectiva intersetorial.

A inclusão da ótica de todos os atores envolvidos no processo de trabalho em saúde, tais como organizações, gestores, profissionais e usuários como agentes ativos, contribui com a construção de uma cultura da inovação em saúde, e sob esta justificativa, o presente estudo ocupou-se em compreender como os gestores das Secretarias Regionais de Saúde e Gerências Regionais de Saúde percebem a EPS como um dispositivo de gestão, na esfera onde atuam.

Através das análises do corpus, emergido das respostas dos participantes, foram organizadas três categorias de análise, e respectivamente seus núcleos de sentido, através dos quais foi possível apreender que embora a Educação Permanente em Saúde seja compreendida pelos participantes como um Processo de Ensino Aprendizado de elevada importância no desenvolvimento de suas atividades cotidianas, estes ainda demonstram dificuldades em delimitar com clareza, a aplicação do conceito em seus contextos de trabalho.

Foram também identificadas dificuldades estruturais e de gestão, tais como o quantitativo reduzido de recursos humanos, a alta rotatividade de pessoal, a sobrecarga de trabalho, a falta de recursos físicos e financeiros, bem como a 
invisibilidade e não valorização das ações já existentes, os quais, são sob a ótica dos participantes, as principais dificuldades que limitam a consolidação da Educação Permanente em Saúde como dispositivo de gestão nestes cenários.

Outro apontamento trazido pela pesquisa diz respeito à necessidade de se repensar os modelos pedagógicos e formativos relacionados à temática, postos na atualidade, à medida que, embora tenham destacado a importância do estudo da temática durante a graduação e pós-graduação, os participantes expressam dificuldades, em aplica-lo como estratégias cotidianas de trabalho.

Embora reconheça-se que ainda exista um longo caminho à ser percorrido, na construção de na consolidação de práticas efetivas, almeja-se que com este estudo, possamos contribuir com as discussões, rumo a superação das lacunas existentes no processo gestão dos SUS, tendo na EPS um importante dispositivo.

Considera-se também relevante, a reflexão sobre a possibilidade do uso de métodos de coleta de dados não tradicionais para as pesquisas qualitativas, destacando que embora ainda exista no meio acadêmico, certa insegurança e resistência quanto à incorporação das tecnologias de comunicação em saúde (TICs) na operacionalização das pesquisas em qualitativas em saúde, sua utilização demonstra-se cada vez mais efetiva, tendo em vista seus relevantes benefícios apontados pela literatura, tais como a redução de custos e recursos ambientais.

Os fatores limitantes deste estudo, relacionam-se com a especificidade de sua natureza qualitativa, pois ao passo que se busca compreender à profundidade dos sentidos das falas dos indivíduos inseridos em suas realidades, desvelamos achados que não podem ser generalizados para outros contextos.

Por fim, destaca-se que além das já mencionadas contribuições no campo da saúde coletiva, o presente trabalho, traz também contribuições para a prática profissional da enfermagem, à medida que seus achados reafirmam o protagonismo do enfermeiro nos cargos de gestão das Secretarias Regionais de Saúde e Gerências Regionais de Saúde estudadas, destacando assim a liderança e autonomia profissional que possuem nestes espaços.

Ao darmos voz aos trabalhadores destas instâncias, esperamos, ter conseguido alcançar nosso objetivo de analisar a Educação Permanente como dispositivo de gestão dos profissionais de saúde nas Superintendências e Gerências Regionais de Saúde de Minas Gerais e ter demonstrado que a EPS se caracteriza como um conceito pedagógico, que busca favorecer as relações entre ensino, 
serviço, e atenção à saúde, atuando nos eixos de formação, gestão, desenvolvimento e controle social.

Cônscios de que novas pesquisas devem ser realizadas, almejamos com este estudo, contribuir com a construção de estratégias de superação das dificuldades evidenciadas, bem como contribuir com as discussões que versem sobre a temática em prol do fortalecimento do Sistema Único de Saúde e suas esferas de gestão, tendo na Educação Permanente em Saúde, um dispositivo de promoção de melhorias no cotidiano de trabalho dos profissionais. 


\section{REFERÊNCIAS}

ALVES, J. C. R. Política Nacional de Educação Permanente no SUS: Estudo da Implementação sob a Perspectiva dos Gestores da Secretaria Municipal de Saúde de Teresópolis em 2006. 2007. Dissertação (Mestrado em Medicina). Rio de Janeiro, Universidade Federal do Rio de Janeiro, 2007.

ATUN, R. A.; KYRATSIS, I.; JELIC, G. et al. Diffusion of complex health innovations: implementation of primary health care reforms in Bosnia and Herzegovina. Health policy and planning, v. 22, n. 1, p. 2839, 2007.

BATISTA, Cássia Beatriz. Movimentos de reorientação da formação em saúde e as iniciativas ministeriais para as universidades. Barbarói, Santa Cruz do Sul, n. 38, p. 97-125, 2013. Disponível em:

Http://Pepsic.Bvsalud.Org/Scielo.Php?Script=Sci Arttext\&Pid=S0104$65782013000100007 \&$ Lng=Pt\&Nrm=Iso Acesso em 10 jun. 2019.

BATISTA, K. B. C.; GONCALVES, O. S. J. Formação dos profissionais de saúde para o SUS: significado e cuidado. Saúde e sociedade, São Paulo, v. 20, n. 4, p. 884-899, dez., 2011. Disponível em:

http://www.scielo.br/scielo.php?script=sci arttext\&pid=S010412902011000400007\&l ng=en\&nrm=iso Acesso em: 10 nov. 2018.

BRASIL, MINISTÉRIO DA SAÚDE - Secretaria de Gestão do Trabalho e da Educação na Saúde. Departamento De Gestão Da Educação Na Saúde. Política Nacional de Educação Permanente dm saúde: o que se tem produzido para o seu fortalecimento?. 1a ed. rev. Brasília: Ministério da Saúde, 2018. Disponível em: http://bvsms.saude.gov.br/bvs/publicacoes/politica nacional educacao permanente saude fortalecimento.pdf Acesso em 10 jun. 2019.

BRASIL. Constituição 1988. Constituição da República Federativa do Brasil, Brasília, Senado Federal, 1988.

BRASIL. Ministério da Educação, Conselho Nacional de Educação. Parecer CNECES 1133/2011 de 03 de outubro de 2001. DIÁRIO OFICIAL DA UNIÃO, BRASÍLIA. SEÇÃO 1E, P. 131. Disponível em:

http://portal.mec.gov.br/dmdocuments/ces1133.pdf Acesso em 10 jun. 2019.

BRASIL. Ministério da Saúde (MS). Secretaria de Gestão do Trabalho e da Educação na Saúde. Departamento de Gestão e da Regulação do Trabalho em Saúde. Câmara de Regulação do Trabalho em Saúde. Brasília: MS; 2006.

BRASIL. Ministério da Saúde. Conselho Nacional de Saúde, Comitê Nacional de Ética em Pesquisa em Seres Humanos. Resolução no 466 de 12 de dezembro de 2012: Diretrizes e normas regulamentadoras de pesquisa envolvendo seres humanos. Brasília; 2012a. Disponível em: http://conselho.saude.gov.br/resolucoes/2012/Reso466.pdf Acesso em: 10 nov. 2018. 
BRASIL. Ministério da Saúde. PORTARIA № 1.996, de 20 de agosto de 2007. Dispõe sobre as diretrizes para a implementação da Política Nacional de Educação Permanente em Saúde. Disponível em:

http://bvsms.saude.gov.br/bvs/saudelegis/gm/2007/prt1996 2008 2007.html Acesso em: 10 jun. 2019.

BRASIL. Ministério da Saúde. Portaria no 1.996, de 20 de agosto de 2007. Dispõe sobre as diretrizes para a implementação da Política Nacional de Educação Permanente em Saúde, DF, 2007.

BRASIL. Ministério da Saúde. Portaria no 198/GM/MS. Política Nacional de Educação Permanente em Saúde. Brasília, DF, 2004b.

BRASIL. Ministério da Saúde. Secretaria de Gestão do Trabalho e da Educação na Saúde, Departamento de Gestão da Educação em Saúde. Política Nacional de Educação Permanente em Saúde. Brasília, DF: Ministério da Saúde; 2009. Disponível em: http://bvsms.saude.gov.br/bvs/publicacoes/politica nacional educacao permanente saude.pdf. Acesso em: 10 nov. 2018.

BRASIL. Ministério da Saúde. Secretária de Gestão do Trabalho e da Educação na Saúde. Departamento de Gestão de Educação Permanente na Saúde. Política de Educação e Desenvolvimento para o SUS: caminhos para a educação permanente em saúde - Polos de Educação Permanente em Saúde. Brasília, 2004a.

BRASIL. Secretaria de Saúde de Minas Gerais. Decreto no 44.155/2005. Dispõe sobre a organização da secretaria de estado de saúde. Belo Horizonte, MG. 2005.

BRASIL; MINISTÉRIO DA EDUCAÇÃO; MINISTÉRIO DA SAÚDE. Portaria interministerial no 10, de 20 de agosto de 2014. Institui a comissão executiva dos contratos organizativos de ação pública ensino-saúde e o comitê nacional dos contratos organizativos de ação pública ensino-saúde. Diário oficial da união, 2014. Disponível em: https://www.poderesaude.com.br/novosite/images/publicacoes 21.08.2014-IV.pdf Acesso em 10 jun. 2019.

CAMPOS, G. W. S; CAMPOS, R, T, O. Dicionário da Educação Profissional em Saúde. Rio de Janeiro: Editora Fio Cruz, 2009.

CAMPOS, K. F. C.; SENA, R.R; SILVA, K. L. Educação profissional permanente em serviços de saúde. Esc. Anna Nery, Rio de Janeiro, v. 21, n. 4, 2017. Disponível em: http://www.scielo.br/scielo.php?script=sci arttext\&pid=S141481452017000400801\&lng=en\&nrm=iso Acesso em: 15 out. 2018.

CARDOSO, I. M. Rodas de Educação Permanente" na Atenção Básica de Saúde: analisando contribuições. Revista de Ciência em Saúde Coletiva.; 21(supl. 1), p.18-28, 2012. 
CASTRO, C.G.J.de; CUNHA, M.L.G.S.; RABELLO, M.C.G.; SÁ, E.N.C.

Administração por convênios: um instrumento gerencial de políticas pública: uma análise dos convênios da Secretaria de Estado da Saúde de São Paulo - 1987, Revista em Sáude Pública, São Paulo, 22(2), 1988.

CECCIM, R. B.; ARMANI, T.; ROCHA, C. O que dizem a legislação e o controle social em saúde sobre a formação de recursos humanos e o papel dos gestores públicos no Brasil, Ciência e saúde coletiva. Rio de Janeiro, v. 7, n. 2, p. 373-383, 2002. Disponível em: http://www.scielo.br/pdf/csc/v7n2/10255.pdf Acesso em 10 jun. 2019.

CECCIM, R. B.; BRAVIN, F. P.; DOS SANTOS, A. A. Educação na saúde, saúde coletiva e ciências políticas: uma análise da formação e desenvolvimento para 0 Sistema Único de Saúde como política pública. Rio de Janeiro: Lugar Comum UFRJ, 2009.

CECCIM, R. B.; PINHEIRO, R.; MATTOS, R. Onde se lê recursos humanos da saúde, leia-se coletivos organizados de produção da saúde: desafios para a educação. Construção social da demanda: direito à saúde, trabalho em equipe, participação e espaços públicos. Rio de Janeiro: Cepesc, p. 161-80, 2005.

COSTA, L. S. Innovation in healthcare services: notes on the limits of field research. Cadernos de saúde pública, Rio de Janeiro, v. 32, supl. 2, 2016.

CUNHA, P. F.; MAGAJEWSKI, F. Gestão Participativa e Valorização dos Trabalhadores: avanços no âmbito do SUS. Saúde e Sociedade, v. 21, 2012.

D'ÁVILA, L.S.; ASSIS, L.N.; MELO, M. B. et al. Adesão ao Programa de Educação Permanente para médicos de família de um Estado da Região Sudeste do Brasil. Revista de Ciência em Saúde Coletiva. (19), p. 401-416, 2014,

EDITAL 07/2017. Programa de pesquisa para o SUS - PPSUSMS/CNPq/FAPEMIG/SES. Disponível em: https://fapemig.br/media/filer public/ee/5f/ee5fff12-1229-4042-8c0e2b35176ab1c9/chamada 07-2017 - ppsus.pdf Acesso em: 07 jun. 2019.

EVASHWICK, C. J; TAO, D; BAX, K. Analysis of the literature pertaining to the education of public health professionals. Front Public Health. 2013. Disponível em: https://www. ncbi.nlm.nih.gov/pmc/ Acesso em: 10 nov. 2018.

FARAH, B. F. Educação em serviço, educação continuada, educação permanente em saúde: sinônimos ou diferentes concepções?. Revista APS, v.6, n.2, p.123-125, Juiz de Fora, jul./dez 2003. Disponível em:

http://www.ufff.br/nates/files/2009/12/Tribuna.pdf Acesso em 10 jun. 2019.

FREIRE, P. Extensão ou comunicação?. Tradução de Rosisca Darcy de Oliveira. $7^{a}$ ed. Rio de Janeiro: Paz e Terra, 1983, 93p. Disponível em: https://www.emater.tche.br/site/arqpdf/teses/Livro P Freire exten sao ou Comunicacao.pdf Acesso em: 10 Nov. 2018. 
FREITAS, J; JANISSEK, R; MOSCAROLA, J. Dinâmica do processo de coleta e análise de dados via web. In: CRIBRAPEQ Congresso Internacional de Pesquisa Qualitativa, 2004.

GADOTTI, M.; FREIRE, P. A educação contra a educação: o esquecimento da educação ea educação permanente. Rio de Janeiro: Paz e Terra, 1987.

GIGANTE, R. L; CAMPOS, G. W. S. Política de formação e educação permanente em saúde no Brasil: bases legais e referências teóricas. Revista Trabalho e educação em Saúde. Nov. 2016. Disponível em:

http://www.scielo.br/scielo.php?script=sci arttext\&pid=S198177462016000300747\&lng=en\&nrm=iso Acesso em: 21 de out. 2017.

GÓES, M. C. R. de. A natureza social do desenvolvimento psicológico. Cadernos Cedes 24, 17-24, 1991.

GOMES. B, L; BARBOSA. M, G; FERLA, A. A. A Educação Permanente em Saúde e as Redes Colaborativas. Porto Alegre: Rede Unida, p. 85 - 88, 2016.

GOOGLE. Introducing Google Drive... yes, really. 2012. Disponível em: https://googleblogspot.com.br/2012/04/introducing-google-drive-yes-really.html Acesso em: 10 nov. 2017.

HADDAD Q., Jorge; ROSCHKE, M. A. C.; DAVINI, M. C. Educación permanente en salud. Washington, D.C; Organizacion Panamericana de la Salud, 1995.

HEIDEMANN, L. A; OLIVEIRA, A. M. M; VEIT, E. A. Ferramentas on line no ensino de ciências: uma proposta com o Google Docs. Física na escola. São Paulo. v. 11, n. 2, 2010, p 30-33.

HOUAISS, A. Dicionário Houaiss da Língua Portuguesa. Rio de Janeiro: Objetiva, 2001. Disponível em: www.houaiss.uol.com.br/busca.jhtm. Acesso em: 10 nov. 2018. http://www.ead.fea.usp.br/cad-pesq/arquivos/C03-art06.pdf Acesso em: 10 nov.

2018.

IBGE- INSTITUTO BRASILEIRO DE GEOGRAFIA E ESTATÍSTICA. Censo demográfico: Resultados Preliminares. Rio de Janeiro, 2018.

LAKATOS, E.M; MARCONI, M. A. Fundamentos de metodologia científica. $7^{a}$ ed. São Paulo: Atlas, 2010.

LEMOS, Cristiane Lopes Simão. Educação Permanente em Saúde no Brasil: educação ou gerenciamento permanente?. Ciência e saúde coletiva, Rio de Janeiro, v. 21, n. 3, p. 913-922, mar. 2016. Disponível em: http://www.scielo.br/scielo.php?script=sci arttext\&pid=S141381232016000300913\&l ng=en\&nrm=iso Acesso em: 10 Nov. 2018.

LOPES, S. R. S. et al. Potencialidades da educação permanente para a transformação das práticas de saúde. Comunicação em ciências da saúde, v. 18, n. 2, p. 147-155, 2007. 
LORENZETTI, J. A enfermagem e os desafios para a saúde no Brasil: propostas para o período 2011-2015. Florianópolis (SC): Coren/SC; 2012. Disponível em: http://www.corensc. Acesso em: 28 out. 2017

LORENZETTI, J. et al. Gestão em saúde no Brasil: diálogo com gestores públicos e privados. Texto \& Contexto Enfermagem, Florianópolis, v. 23, n. 2, p. 417-425, 2014. Disponível em: https://goo.gl/9uLDzn Acesso em: 10 nov. 2018.

MARX, K. O capital: crítica da economia política. Tradução de Regis Barbosa e Flávio R. Kothe. 2. São Paulo: São Paulo,1987.

MATOS, E; PIRES. D. Teorias Administrativas e Organização do Trabalho: de Taylor aos dias atuais, influencias no setor saúde e na enfermagem. Texto Contexto Enfermagem, 2006.

MERHY, E. E. Educação Permanente em Movimento: uma política de reconhecimento e cooperação, ativando os encontros do cotidiano no mundo do trabalho em saúde, questões para os gestores, trabalhadores e quem mais quiser se ver nisso. Saúde em Redes, v. 1, n. 1, p. 07-14, 2014.

MINAS GERAIS. Legislação Mineira. Decreto 45.812 de 14 de dezembro de 2011. Dispões sobre a organização da Secretaria de Estado de Saúde de Minas Gerais. Disponível em: https://www.almg.gov.br/consulte/legislacao/completa/completa-novamin.html?tipo=Dec\&num=45812\&ano=2011 Acesso em: 07 jun. 2019.

MINAYO, M. C. S. Desafio do conhecimento: pesquisa qualitativa em saúde. 14. ed. São Paulo: Hucitec; 2014.

MORAES, K. G; DYTZ, J. L. G. Política de educação permanente em saúde: análise de sua implementação. ABCS Health Sci. 40(03), p. 263-9, 2015.

NEVES, J. L. Pesquisa qualitativa: características, usos e possibilidades. Caderno de Pesquisas em Administração, São Paulo, v. 1, n. 3, 1996. Disponível em:

OLIVEIRA, W. B; JACINSKI, L. Desenvolvimento de Questionário para a Coleta e Análise de Dados de uma Pesquisa, em Substituição ao Modelo Google Forms. Universidade Tecnológica Federal do Paraná. Ponta Grossa. 2017.

ORGANIZAÇÃO PAN-AMERICANA DA SAÚDE. Educacíon permanente de personal de salud em la regíon de las américas. Washington: OPAS; Fascículo I: Propuesta de reorientatión. Fundamentos. Série de desarrolo de recursos humanos, n 78. Organização Pan-Americana da Saúde, 1988.

PAIM, J.S. Descentralización de las Acciones y Servicios de salud en el Brasil y la renovación de la propuesta "Salud para Todos. Conferencia Regional sobre Tendencias Futuras y Renovación de Salud para Todos. Montevideo, Uruguay, p. 9-12 de Junio de 1996. 
PEDUZZI, M. et al. (2009). Atividades educativas de trabalhadores na atenção primária: concepções de educação permanente e de educação continuada em saúde presentes no cotidiano de Unidades Básicas de Saúde em São Paulo. Interface, Botucatu, v. 13 (30). Disponível em: www.scielo.br/scielo.php?script=sci arttext\&pid=S141432832009000300011\&lng=en \&nm=iso Acesso em: 07 jun. 2019.

PINHEIRO, Guilherme E. W.; AZAMBUJA, M. S. de e BONAMIGO, Andrea W. Facilidades e dificuldades vivenciadas na Educação Permanente em Saúde, na Estratégia Saúde da Família. Saúde em Debate. v. 42, n. 4, pp. 187-197, 2018. Disponível em: https://doi.org/10.1590/0103-11042018S415 Acesso em 6 jun. 2019.

PINO, A. e GÓES, M.C. de. Pensamento e Linguagem. Caderno CEDES, 24, p. 5-9, 1991.

RESTINI, Carolina Baraldi Araujo; FERNANDES, Nicole Maset; MARINZECK, Leonardo Castro et al. Gestão de ensino na saúde: relevância na formação do gestor no contexto da saúde brasileira. Revista de Teorias e Práticas

Educacionais, vol. 5, n.1, p. 05-11, 2014. Disponível em:

https://www.mastereditora.com.br/periodico/20141102 174748.pdf Acesso em 10 jun. 2019.

RIBEIRO, E.C.O.; MOTTA, J.I.J. Educação permanente como estratégia na reorganização dos serviços de saúde. Divulgação em Saúde Para Debate, n. 12, p. 39-44, jun. de 1996.

RIBEIRO, K. S. Q. A atuação da fisioterapia na atenção primária à saúde.

Fisioterapia Brasil, v.3, n.5, p. 311-318, 2002.

ROSSETTI, L. T. Educação permanente como ferramenta de gestão do sistema único de saúde: a concepção dos enfermeiros. 2015. Dissertação (Mestrado em Enfermagem) - Faculdade de Enfermagem, Universidade Federal de Juiz de Fora, Juiz de Fora, 2015.

SÁ, Evelin Naked de Castro; DIMITROV, Pedro. Funções da Secretaria de Estado da Saúde no Sistema Único de Saúde (SUS) de São Paulo. Debate, São Paulo, 2(2), p. 1-22, 1993.

SARDINHA PEIXOTO, Leticia; CUZATIS Gonçalves, Ludimila; DUTRA DA COSTA, Tiago et al. Educação permanente, continuada e em serviço: desvendando seus conceitos. Enfermería Global. n. 29, 2013. Disponível em:

http://scielo.isciii.es/pdf/eg/v12n29/pt revision1.pdf Acesso em 10 jun. 2019.

SILVA, C. T; TERRA, M. G; CAMPONOGARA, S; KRUSE, M.H. L; ROSO, C. C; XAVIER, M.S. Permanent health education based on research with professionals ofa multidisciplinary residency program: case study. Revista Gaúcha de Enfermagem, 35(3): p. 49-54, 2014. 
SILVA, K. L; MATOS, J. A. V; FRANÇA, B. D. A construção da educação permanente no processo de trabalho em saúde no estado de Minas Gerais, Brasil. Rev. Escola de Enfermagem Anna Nery, v. 21, n. 04, Juiz de Fora, 2017.

SILVA, M. N.; FLAUZINO, R. F.; GONDIM, G.M.M. Rede de Frio: fundamentos para compreensão do trabalho. 22ª ed. Rio de Janeiro: Fiocruz, 2017.

SILVA, V. R.; DA SILVA, M. D. G.; DOS SANTOS, L. B. O. Proposta pedagógica do PROFAE na perspectiva dos enfermeiros instrutores. Revista Brasileira de Enfermagem, v. 58, n. 3, p. 284-289, 2005.

SILVA, William Ávila de Oliveira. A educação permanente como dispositivo de gestão do Sistema Único de Saúde: teste de instrumento e procedimentos.

Trabalho de Conclusão de Curso (Graduação em Enfermagem). 2018, Juiz de Fora, Universidade Federal de Juiz de Fora, 2018.

SMAHA, I. N.; CARLOTO, C. M. Educação permanente: da pedagogia para a saúde. VII Seminário do Trabalho: trabalho, educação e sociabilidade. p. 24-28, 2010.

SPAGNOL, Carla Aparecida. (Re)pensando a gerência em enfermagem a partir de conceitos utilizados no campo da Saúde Coletiva. Ciência e saúde coletiva, Rio de Janeiro, v. 10, n. 1, p. 119-127, mar. 2005.

VYGOTSKY, L. S. A Formação Social da Mente. São Paulo: Martins Fontes, 2010.

ZANINI, M. Formulários eletrônicos. 2007. 21p. Universidade Federal de Santa Catarina, Florianópolis. Disponível em:

https://projetos.inf.ufsc.br/arquivos_projetos/projeto_698/artigo.pdf Acesso em: 10 de nov. 2017. 


\section{ANEXO A - TERMO DE CONSENTIMENTO LIVRE E ESCLARECIDO}

O Sr. (a) está sendo convidado (a) como voluntário (a) a participar da pesquisa EDUCAÇÃO PERMANENTE COMO DISPOSITIVO DE GESTÃO DO SISTEMA ÚNICO DE SAÚDE. Nesta pesquisa pretendemos analisar a Educação Permanente como dispositivo de gestão dos profissionais de saúde nas Superintendências e Gerências Regionais de Saúde de Minas Gerais. O motivo que nos leva a estudar a presente temática, fundamenta-se na possibilidade de melhoria assistencial, através da compreensão da Educação Permanente como dispositivo de gestão no âmbito do Sistema Único de Saúde brasileiro. Para esta pesquisa adotaremos os seguintes procedimentos: ao concordar em participar você responderá a um questionário eletrônico, através do qual, o pesquisador extrairá as informações necessárias por análise das respostas. Os riscos envolvidos na pesquisa consistem em riscos mínimos, sendo assegurado o compromisso em se maximizar os benefícios e se minimizar os danos e riscos, que podem ser subjetivos, como a manifestação de diferentes sentimentos, incluindo o constrangimento ao responder alguma pergunta. Você, enquanto participante será esclarecido quanto a estes e lhe será dada completa autonomia para interromper sua participação, sem que isso interfira na relação entre pesquisador, participante. Além disso, lhe será assegurada a manutenção do anonimato e do sigilo relacionado à sua identificação pelas informações. A pesquisa contribuirá com o aperfeiçoamento das ações educacionais através da educação permanente em saúde para os profissionais de saúde gestores nas superintendências regionais de saúde de Minas Gerais pode ter impacto nas ações dos serviços de saúde e melhoria da assistência a população de Minas Gerais. Para participar deste estudo o Sr (a) não terá nenhum custo, nem receberá qualquer vantagem financeira. Apesar disso, caso sejam identificados e comprovados danos provenientes desta pesquisa, o Sr.(a) tem assegurado o direito a indenização. O Sr. (a) terá o esclarecimento sobre o estudo em qualquer aspecto que desejar e estará livre para participar ou recusar-se a participar. Poderá retirar seu consentimento ou interromper a participação a qualquer momento. A sua participação é voluntária e a recusa em participar não acarretará qualquer penalidade ou modificação na forma em que o Sr. (a) é atendido (a). O pesquisador tratará a sua identidade com padrões profissionais de sigilo. Os resultados da pesquisa estarão à sua disposição quando finalizada. Seu nome ou o material que 
indique sua participação não será liberado sem a sua permissão. O (A) Sr (a) não será identificado (a) em nenhuma publicação que possa resultar. Este termo de consentimento encontra-se impresso em duas vias originais, sendo que uma será arquivada pelo pesquisador responsável, na FACULDADE DE ENFERMGEM DA UNIVERSIDADE DE JUIZ DE FORA e a outra será fornecida ao Sr. (a). Os dados e instrumentos utilizados na pesquisa ficarão arquivados com 0 pesquisador responsável por um período de 5 (cinco) anos, e após esse tempo serão destruídos. Os pesquisadores tratarão a sua identidade com padrões profissionais de sigilo, atendendo a legislação brasileira (Resolução № 466/12 do Conselho Nacional de Saúde), utilizando as informações somente para os fins acadêmicos e científicos.

$\mathrm{Eu}$, portador do documento de Identidade fui informado (a) dos objetivos da pesquisa EDUCAÇÃO PERMANENTE COMO DISPOSITIVO DE GESTÃO DO SISTEMA ÚNICO DE SAÚDE, de maneira clara e detalhada e esclareci minhas dúvidas. Sei que a qualquer momento poderei solicitar novas informações e modificar minha decisão de participar se assim o desejar.

Declaro que concordo em participar. Recebi uma via original deste termo de consentimento livre e esclarecido e me foi dada à oportunidade de ler e esclarecer as minhas dúvidas.

Juiz de Fora, de de 20 .

Assinatura do Participante

Assinatura do (a) Pesquisador (a)

Nome do Pesquisador Responsável: Denise Barbosa de Castro Friedrich Endereço: RUA IVON JOSÉ CURI 368 PORTAL DA TORRE CEP: 36037-467 / Juiz de Fora - MG Fone: (32) 32362474 E-mail: denise.friecrich@ufff.edu.br. 
ANEXO B - PARECER CONSUSBSTANCIADO CEP/UFJF

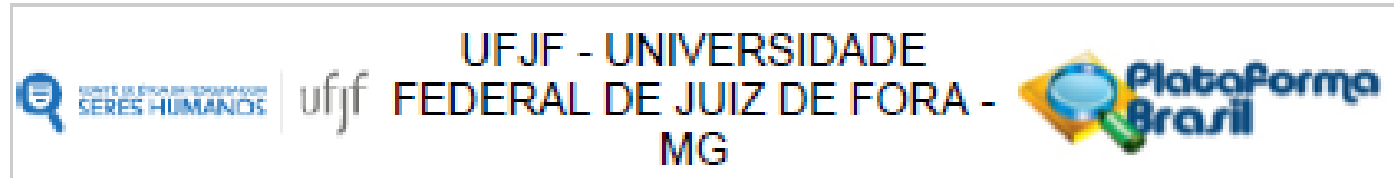

\section{PARECER CONSUBSTANCIADO DO CEP}

\section{DADOS DO PROJETO DE PESQUISA}

Título da Pesquisa: ĘDUCACÃO PERMANENTE COMO DISPOSITIVO DE GESTÃO DO SISTEMA UNICO DE SAUDE

Pesquisador: Denise Barbosa de Castro Friedrich

Área Temática:

Versão: 2

CAAE: 77983617.8 .0000 .5147

Instituiçäo Proponente: Faculdade de Enfermagem

Patrocinador Principal: Financiamento Próprio

\section{DADOS DO PARECER}

Número do Parecer: 2.400 .588

Apresentaçäo do Projeto:

Trata-se de um estudo de abordagem qualitativa, do tipo descritivo, baseado no referencial teóricometodológico da hermenêutica-dialética. $O$ cenário do estudo serão as 28 superintendências e gerèncias regionais de saúde do estado de Minas Gerais. Os participantes seräo profissionais de saúde que trabalham na gestão de projetos e programas desenvolvidos nas superintendèncias junto aos municipios de área de abrangência. A coleta de dados será através de questionário elaborado através formulários eletrônicos gratuitos. A análise de dados será através da Hermenêutica Dialética. Espera-se que os resultados demonstrem a importância das açōes educacionais através da educaçăo permanente em saúde para os profissionais de saúde gestores nas superintendèncias regionais de saúde de Minas Gerais. Apresentação do projeto está clara, detalhada de forma objetiva, descreve as bases científicas que justificam o estudo, estando de acordo com as atribuições definidas na Resolução CNS 468/12 de 2012, item III.

Objetivo da Pesquisa:

Objetivo Primário:

Analisar a Educação Permanente como dispositivo de gestão dos profissionais de saúde nas Superintendẻncias e Gerências Regionais de Saúde de Minas Gerais.

Objetivo Secundário:

1. Compreender como se dá o trabalho dos profissionais de saúde atuantes nas Gerências e

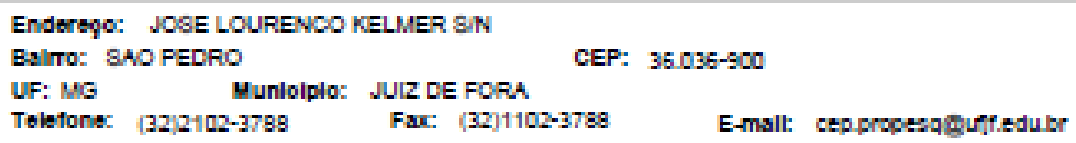




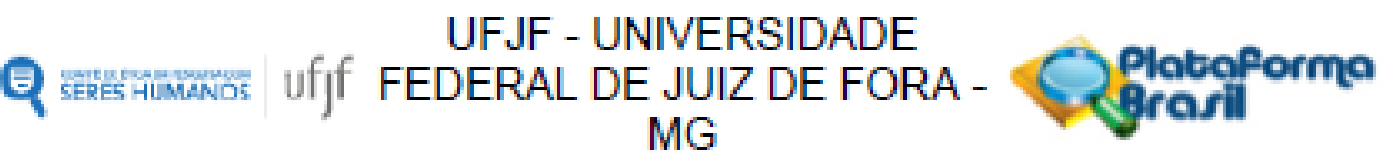

Centinuacto de Parecer. 2.400 .568

superintendências- MG;2. Identificar como os profissionais de saúde concebem a Educaçäo Permanente como dispositivo de gestäo; 3 . Descrever quais práticas de EP säo realizadas nos processos de gestão pelos profissionais de saúde e quais são os atores envolvidos.

Os Objetivos da pesquisa estão claros bem delineados, apresenta clareza e compatibilidade com a proposta, tendo adequação da metodologia aos objetivos pretendido, de acordo com as atribuições definidas na Norma Operacional CNS 001 de 2013, item 3.4.1 - 4 .

Avaliação dos Riscos e Beneficios:

Riscos e benefícios descritos em conformidade com a natureza e propósitos da pesquisa. O risco que o projeto apresenta é caracterizado como risco mínimo e beneficios esperados estão adequadamente descritos. A avaliaçäo dos Riscos e Beneficios está de acordo com as atribuiçôes definidas na Resolução CNS 468/12 de 2012, itens III; III. 2 e V.

Comentários e Considerações sobre a Pesquisa:

O projeto está bem estruturado, delineado e fundamentado, sustenta os objetivos do estudo em sua metodologia de forma clara e objetiva, e se apresenta em consonảncia com os princípios éticos norteadores da ética na pesquisa científica envolvendo seres humanos elencados na resolução $468 / 12$ do CNS e com a Norma Operacional No 001/2013 CNS.

Considerações sobre os Termos de apresentação obrigatória:

O protocolo de pesquisa está em configuração adequada, apresenta FOLHA DE ROSTO devidamente preenchida,com o título em portugués, identfica o patrocinador pela pesquisa, estando de acordo com as atribuiçöes definidas na Norma Operacional CNS 001 de 2013 item 3.3 letra a; e 3.4.1 item 16. Apresenta o TERMO DE CONSENTIMENTO LIVRE ESCLARECIDO em linguagem clara para compreensäo dos participantes, apresenta justificativa e objetivo, campo para identificação do participante, descreve de forma suficiente os procedimentos, informa que uma das vias do TCLE será entregue aos participantes,assegura a liberdade do participante recusar ou retirar o consentimento sem penalidades, garante sigilo e anonimato, explicita riscos e desconfortos esperados, indenizaçăo diante de eventuais danos decorrentes da pesquisa,contato do pesquisador e do CEP e informa que os dados da pesquisa ficarão arquivados com o pesquisador pelo periodo de cinco anos, de acordo com as atribuições definidas na Resoluçäo CNS 466 de 2012, itens:IV letra b; IN.3 letras a,b,d,e,f,g e h; IV. 5 letra d e XI. 2 letra f. Apresenta o INSTRUMENTO DE COLETA DE DADOS de forma pertinente aos objetivos delineados e preserva os participantes da pesquisa. O Pesquisador apresenta titulaçăo e experiëncia compativel com o projeto de pesquisa, estando de acordo com as atribuiçôes definidas no Manual Operacional para

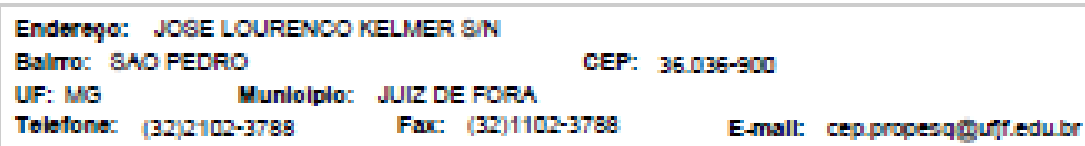




\section{ANEXO C - CORPUS}

1- O que você compreende por educação permanente em saúde?

- Compreendo a educação permanente como uma ferramenta para melhoria das práticas cotidianas; para qualificar o trabalho.

- Tem como objetivo o processo de trabalho e como propósito melhorar a qualidade de vida das pessoas abrangendo dimensões pessoais e sociais, ajudando na formação, transformando a realidade.

- É importante a participação de todos, analisando o contexto, identificando os entraves, planejando, monitorando e avaliando para qualificar a atenção à saúde, os processos formativos, as práticas de educação em saúde, além de incentivar a organização das ações e dos serviços numa perspectiva intersetorial.

- Trajetória de capacitações que permitem que o servidor se atualize nas temáticas voltadas à saúde relevantes para o desempenho de suas funções

- Atividades realizadas no ambiente de trabalho com intuito de fortalecimento das ações, mudança ou transformação de práticas institucionais.

- É um processo de formação que se desenvolve a partir de um problema do serviço/rotina de trabalho ou da problematização, devendo ocorrer a partir de um cronograma, de forma sistemática e para pequenos grupos de trabalhadores (10 a 12 pessoas no máximo em cada grupo).

- Aperfeiçoamento constante pessoal e laboral que incide em seu trabalho.

Processo de mudança de paradigmas no trabalho das instituições, com integração nos diversos segmentos.

- E ser atualizada com os temas relevantes para nossa atuação

- EPS é uma estratégia de qualificação e aperfeiçoamento do processo de trabalho, no qual os profissionais a partir de problemas identificados buscam a melhoria das práticas e da qualidade dos serviços.

- Discussão e Construção de diretrizes e ações em educação permanente no SUS como um todo para melhor integração de todos os trabalhadores envolvidos, em todas as áreas e prestação de serviços.

- Compreendo que seja uma prática de ensino-aprendizagem, onde acontece o compartilhamento de experiências e ensinamentos.

- Entendo como uma proposta pedagógica que visa qualificar os profissionais que atuam no âmbito do SUS em todos os níveis de atenção.

- Educação permanente em saúde é um tipo de prática de ensino e aprendizagem, pautada no contexto do serviço, que tem como objetivo identificar instrumentos e formas de enfrentamento dos problemas existentes na prática profissional. Requer participação inter e multidisciplinar, diálogo e reflexão dos processos de trabalho para identificar formas de enfrentamento às dificuldades encontradas.

- Processo de ensino-aprendizagem relacionado à atuação no campo da saúde, ocorrendo de modo planejado a partir da avaliação das necessidades e potencialidades presentes no local de realização. Deve ocorrer de modo permanente e envolver equipamentos adequados a fim de facilitar sua efetivação. Também deve passar por etapas de monitoramento e avaliação.

- Proposta que visa qualificar os serviços de saúde.

- Estudo e atualização de conhecimentos constantes.

- É a Educação em Serviço; com conteúdos relacionados ao processo de trabalho dos profissionais.

- Processo de treinamentos contínuos e selecionados de acordo com a necessidade das equipes de atenção básica.

- Toda e qualquer ação que coloque o. cotidiano do trabalho em discussão, analise e reflexão com vistas às melhorias do cuidado em saúde tanto para o trabalhador quanto para o usuário.

- Educação sobre temas importantes do dia a dia no trabalho. 
- Uma ação contínua de ensino e aprendizagem, uma troca de saber, um aprimoramento da prática de trabalho a fim de qualificar o atendimento realizado ao público alvo e para a gestão pública como um todo.

- Parte do pensar e do fazer dos trabalhadores propiciando o crescimento pessoal e profissional destes, para a organização do processo de trabalho que possam problematizar a realidade e produzir mudanças no cotidiano

- Processos de ensino aprendizado sistematizados.

- É a implementação de estratégias de desenvolvimento profissional através de capacitações, reuniões, rodas de conversa, dinâmicas de grupo ou outras tecnologias aplicadas com regularidade.

- Qualificação e atualização profissional contínua

- Produção de conhecimentos no cotidiano a partir da realidade vivenciada pelos profissionais, tendo os problemas enfrentados no dia-a-dia do trabalho e as experiências como base para questionamentos e mudanças.

Reflexão sobre a Prática, construção coletiva, aprendizagem significativa, aprendizagem no trabalho para o trabalho.

- Prática de ensino-aprendizagem e política de educação na saúde, tendo em vista a cidadania e a educação no trabalho. Processo ensino aprendizagem que considera as vivências cotidianas do profissional em serviço.

- A oportunidade de realizar momentos de encontro, discussão e formação, que tenham potencial transformador em minha prática profissional e no trabalho.

- Capacitações ministradas ao profissionais de saúde a partir de uma demanda ou problemas enfrentados na rotina.

- Ferramenta para reconhecermos a produção local de cotidianos de saúde e ativar práticas colaborativas de aprendizagem em saúde.

- A Educação Permanente em Saúde busca na interação coletiva construir conhecimento, problematizar, implementar e avaliar de modo permanente as ações para fortalecimento das boas práticas, valorizando o potencial dos recursos humanos disponíveis no território com horizontalidade. Neste espaço, valoriza-se a demanda de ação educacional que surge a partir da fragilidade ou desafio observados no território, tornando o processo ativo, humanizado, dinâmico e efetivo para transformação da realidade e fortalecimento do SUS. Esta construção coletiva prescinde articulação e envolvimento de todos os atores envolvidos no processo de trabalho - profissionais de saúde e gestores.

- Todo e qualquer tipo de atividade de educação/treinamento/capacitação com tema relacionado à saúde.

- Uma estratégia que deve ser aplicada no ambiente de trabalho

- É um tipo de educação e capacitação do profissional que acontece de forma continuada.

- Todo e qualquer tipo de capacitação/atividade de educação relacionados à saúde.

- Qualquer ação que contribua para o crescimento profissional, desde rodas de conversas à capacitações.

- É um modelo de formação problematizadora, baseada nos aspectos vivenciados no cotidiano do trabalho. Requer que o profissional, com base nas demandas e fragilidades apresentadas no cotidiano do serviço, busque aplicar conhecimentos ou buscá-los de forma a resolver ou minimizar tais problemas. É a formação em serviço e no contexto específico.

2- Em seu contexto de trabalho, quais ações de educação permanente em saúde são realizadas? Para quem essas ações são direcionadas?

- "Dentro do meu contexto, entendo que as práticas de educação permanente são realizadas a todo momento.

- É uma ferramenta do meu trabalho enquanto referência técnica, uma vez que os municípios se reportam a mim para sanar dúvidas, questionar determinadas situações e comunicar problemas que permeiam o programa em que sou referência. Portanto, é necessário identificar naquele contato questões importantes que devem ser trabalhadas, 
reforçando algumas informações e auxiliando a construir um novo processo de trabalho. $\mathrm{E}$ também há ações programadas, que são agendadas a partir de um problema, uma situação nova e/ou alguma alteração realizada dentro do programa.

- São ações do tipo oficinas, encontros e que as vezes acontecem até mesmo através telefonemas, whatssap e e-mail.

- As ações em sua maioria são voltadas para profissionais atuantes na área de vigilância em saúde e na atenção primária, especialmente a equipe de enfermagem.

- "Os cursos de capacitação ministrados pela SES para os técnicos; atualizações de protocolos para as condutas frente os agravos; organização de ações intersetoriais dentre outras. As ações de educação permanente são direcionadas aos técnicos da GRS bem como aos técnicos dos municípios de abrangência.

- No momento nenhuma

- Apenas para municípios da GRS.

- Não temos ação de educação permanente com a concepção descrita anteriormente. Temos capacitações eventuais atendendo à demanda de municípios. Ex: operacionalização do Sistema e-SUS, abordagem e oferta de tratamento ao tabagista, processos de trabalho em Odontologia. As ações são direcionadas aos coordenadores de Atenção Primária e eventual aos alunos dos cursos de saúde (principalmente Enfermagem e Odontologia) da UFVJM, quando solicitado.

- Nossa equipe NAPRIS não recebeu nenhuma ação de EP nos últimos 4 anos.

- Alinhamento das políticas de atenção primária aos técnicos municipais, principalmente com capacitação dos coordenadores municipais de atenção básica.

- Encontros Reuniões para Coordenação e Referencias de programas

- Ações relacionadas à promoção da saúde, avaliação do PMAQ, análise dos resultados dos indicadores, reuniões temáticas, reuniões com os profissionais dos municípios e da própria GRS.

- Como RT em EPS palestras na área de saúde, direcionar cursos aos colegas.

- Realizamos ações de capacitações e atualização dos profissionais municipais, como por exemplo treinamento de Agentes Comunitários de Saúde, Equipes de Saúde da Família, NASF's, sistema de informação da Atenção Básica, etc.

- Fazemos rotineiramente treinamentos em diversos assuntos, principalmente com coordenadores da Atenção Básica e Coordenadores de Saúde Bucal para que qualifiquem seu trabalho e possam orientar e direcionar com qualidade o trabalho dos outros profissionais de seu município.

- As ações realizadas são capacitações para os profissionais de atenção básica dos municípios sob nossa jurisdição, seja por solicitação dos gestores, seja por identificação do setor de fragilidades ou problemas na condução das ações preconizadas. Em alguns momentos também são direcionadas ações aos próprios gestores, sempre com a temática das políticas de saúde vigentes.

- Do nível central para as regionais, encontros normalmente relacionados a demandas levantadas de ambas as partes, muitas vezes a partir de situações mais urgentes e sem planejamento semestral/anual, direcionadas aos técnicos do NAPRIS; do NAPRIS para os municípios, de planejamento a partir de demanda sentida dos municípios ou levantada por eles, ou a partir de sugestão /ordenamento do nível central, tanto para profissionais da coordenação/gestão quanto para os das equipes da Estratégia de Saúde da Família.

- Última foi o Curso Gestão da Clínica. Direcionada para todos os profissionais que atuam na área de saúde.

- Capacitações para coordenadores e enfermeiras e recentemente iniciamos capacitações para ACSs

- Trabalhamos o tempo inteiro com educação permanente. $1^{0}$ o nível central nos capacita e tão logo capacitamos os municípios

- Fluxos assistenciais, trabalhos intersetoriais, necessidades das equipes.

- Discussão de processos de trabalho referentes às temáticas que sou referência (alimentação e nutrição, Programa Bolsa Família). São direcionadas aos coordenadores municipais de atenção primária. 
- São realizadas ações de Educação Permanente para os profissionais dos municípios sobre temas específicos da Políticas de Saúde vigentes

-Reuniões mensais com a equipe

-Desenvolvemos ações de educação continuada com os municípios da jurisdição da SRS Passos

-Reuniões técnicas, oficinas, cursos e capacitações direcionadas aos profissionais técnicos de saúde dos municípios.

-São realizadas capacitações e reuniões de equipe direcionadas aos próprio servidores e aos municípios apoiados pela SRS.

- Capacitações e oficinas oferecidas pelas coordenações estaduais dos programas, são ofertadas ações pelo nível central para as referências técnicas e coordenadores de Napris, bem como são realizadas ações locais no Napris para aperfeiçoamento da equipe. - Rodas de conversa, oficinas. Para trabalhadores das SMS

- Treinamentos, rodas de conversas, oficinas direcionadas para Coordenadores Municipais de APS, profissionais das equipes Atenção Básica e gestores municipais em geral.

- Oficinas, seminários, treinamentos, rodas de conversas, reuniões, comitês. As ações são direcionadas ao melhoramento do serviço do SUS aos usuários, bem como, a melhoria da performance profissional dos servidores da GRS.

- Agentes de saúde, enfermeiros, técnicos de enfermagem e médicos, para cada categoria profissional levanta se uma demanda.

- Reuniões de Equipe/ Intersetoriais. Ações direcionadas aos servidores da SRS e profissionais de saúde dos Municípios/ Gestão Municipal

- As ações que EPS que apoio são voltadas para a $A B$ enquanto coordenadora e ordenadora das redes de atenção à saúde e sendo assim, impactam em outros pontos da redes. Recentemente tivemos uma experiência de EPS bastante exitosa, com o objetivo de explorar o potencial máximo da $A B$ no território de um município a partir da racionalização dos encaminhamentos para média complexidade.

- Reuniões técnicas, workshops, capacitações, rodas de conversa. A maioria dos encontros é direcionado para os técnicos municipais de promoção da saúde, com a finalidade de aprimorar os indivíduos e consequentemente melhorar a assistência prestada aos usuários.

- Realizamos ações com os profissionais dos municípios sobre temáticas relevantes a Atenção Primária.

- Capacitação dos gestores municipais das políticas e programas de Promoção da Saúde.

- Capacitações ao municípios de nossa região de saúde

- As ações acontecem informalmente, diante das demandas que surgem de apoio aos municípios ou de fragilidades que encontramos em relação aos processos de trabalho das equipes que acompanhamos. Não há ações programadas a longo prazo.

3- Quais são os principais desafios que você identifica para a implementação e consolidação da Educação Permanente em seu ambiente de trabalho?

- Acredito que a sobrecarga de demandas, a falta de planejamento - não há um calendário de educações - elas ocorrem somente quando identificadas as necessidades e a baixa valorização deste tipo de ação, não há um entendimento de que ações deste tipo impactam no nosso trabalho.

- A disponibilidade de tempo para capacitação devido à falta de planejamento antecipado para a mesma. Ela não é sistematizada.

- Falta de hábito dos servidores devido ao longo tempo sem esta prática; sensibilização dos mesmos quanto à importância da formação continuada; sobrecarga de trabalho devido à falta de reposição de servidores aposentados.

- A incorporação das discussões nas atividades diárias de trabalho.

-Falta de recursos humanos (somos apenas três servidoras e uma irá afastar para licença maternidade). 
- Maior investimento e compromisso na área.

- Disponibilidade dos municípios em liberar seus servidores para participarem dos eventos.

- Recursos Humanos e dedicação, falta de interesse de profissionais, dificuldades em se estabelecer uma intersetorialidade.

- Colaboração de todos de uma forma geral

- Estrutura e acesso.

- A falta de continuidade no trabalho pela rotatividade de profissional.

- Dificuldade de articulação intersetorial. Resistência de alguns profissionais em participar dos processos de discussão. Falta de capacitação para nós, enquanto Estado, no sentido de prestar apoio mais próximo aos municípios para suas demandas. Falta de recursos humanos para desempenhar todas as funções esperadas.

"- Alta demanda de outras situações de trabalho, com sobrecarga de atribuições dos servidores ou falta de motivação deles;

- Necessidade de organização do processo de EPS, com diagnóstico da situação atual, planejamento e avaliação do trabalho a ser e já desenvolvido;

- Falta de percepção da gestão local da importância da EPS;

- Planejamento e efetivação por parte do nível central de uma Política de EPS."

- Falta de Recurso Humano.

- Falta de planejamento

- Alta rotatividade de gestores; mudanças nas políticas de saúde

- Instabilidade dos cargos, pouca interesse dos profissionais

- Ausência de ofertas de espaços efetivos para reflexão da prática do trabalho e falta de agenda/ espaço reservado para tal demanda.

- No meu ambiente de trabalho acredito que o principal desafio é realmente o trabalho em equipe.

- Rotatividade de profissionais e falta de tempo para dedicação aos estudos, uma vez que a saúde pública é regida por muitas metas de trabalho.

- Perfil profissional, motivação

- Dificuldade financeira e de apoio da gestão

- Planejamento, acordo do grupo em definir datas e estratégias, capacitação para implementação de recursos didáticos eficazes.

- Disponibilização de recursos financeiros e materiais.

- Dificuldades de criar e manter uma agenda de EP em meio as demandas diárias.

- Aumentar a Visibilidade da EPS enquanto potência de mudança no território

- Executar os planejamentos tendo em vista as limitações de $\mathrm{RH}$ e dificuldades financeiras; manter-se motivado diante das dificuldades e motivar os demais atores envolvidos.

- Compatibilidade de agenda.

- Politicas de implementação de educação permanente.

- $\mathrm{RH}$ reduzido, acúmulo de responsabilidades, disponibilidade dos servidores e ausência de horário protegido para que a EPS aconteça de forma mais formalizada.

- Falta de conscientização, apoio e priorização da ferramenta enquanto potente transformadora das práticas em saúde.

- Quando qualificamos multiplicadores, com objetivo que eles retornem ao município e façam a multiplicação in locu, geralmente a multiplicação no município não acontece, ou não acontece de forma satisfatória.

- Atendimentos de média e alta complexidade

- Falta de interesse dos profissionais e falta de tempo hábil para implementar. Além de ausência de capacitação em metodologias ativas que são mais eficientes.

- Tempo curto para planejamento e desenvolvimento de atividades de Educação.

- Permanente devida à outras demandas técnicas institucionais.

- Escassez de recursos humanos 
- Valorização da educação permanente como ferramenta importante para melhoria dos processos de trabalho. Sistematização de um planejamento que considere períodos/espaços para o desenvolvimento de ações de educação permanente no setor e entre setores. Falta de um profissional específico que auxilie na coordenação e planejamento das ações de educação permanente que envolva os diversos setores.

4- Quais são os principais desafios que você identifica para a implementação e consolidação da Educação Permanente nos territórios e nos municípios de sua abrangência?

- Desinteresse dos profissionais; Sobrecarga de trabalho e ausência de supervisão capaz de identificar problemas que poderiam ser resolvidos através de ações de educação permanente.

- A disponibilidade de tempo para capacitação devido a falta de planejamento antecipado para a mesma. Ela não é sistematizada.

- Alta rotatividade de funcionários; sobrecarga de trabalho devido à falta de reposição de servidores; sensibilização dos gestores quanto à necessidade de implementação dessa rotina.

- Recursos monetários.

- Falta de recursos humanos, falta de sistematização da Educação Permanente, por parte da SES/MG e falta de se pensar ou idealizar um PEP para outras categorias profissionais além do médico.

- Maior investimento e compromisso na área.

- Grande abrangência da área de atuação da SRS Teófilo Otoni (32 municípios com mais de 150 equipes.

- Recursos Humanos e Comprometimento com o programa atualização

- Não compreensão por parte dos gestores da importância em se estabelecer uma educação permanente efetiva falta de conhecimento sobre os objetivos e proposta da EPS, rotatividade dos profissionais

- Elaboração do Plano em Educação Permanente anexado ao Plano Municipal dentro da realidade de cada município, que no caso estaria sendo idealizado agora

- Interesse por parte dos municípios.

- Comprometimento dos profissionais, a instabilidade dos mesmos no serviço, a mudança das diretrizes das políticas a cada troca de gestão do governo federal e estadual.

- Pouca priorização dos processos de planejamento pelos municípios. Sobrecarga de profissionais com acúmulo de tarefas e atribuições. Falta de articulação intra e intersetorial. Pouca valorização por parte dos gestores dos processos de educação permanente. Valorização do tempo despendido na clínica em detrimento de atribuir aos profissionais da rede as ações de educação permanente.

- Alta demanda de outras situações de trabalho, com sobrecarga de atribuições dos servidores ou falta de motivação deles; Necessidade de organização do processo de EPS, com diagnóstico da situação atual, planejamento e avaliação do trabalho a ser e já desenvolvido; Dificuldade financeira dos municípios; Desmotivação de algumas realidades com a APS e sua efetividade."

- Falta de Recurso Humano bem como a falta de interesse dos Gestores.

- Disponibilidade de agenda.

- Alta rotatividade de gestores e profissionais da ponta.

- Falta de recurso financeiro, instabilidade dos cargos.

- Entendimento dos profissionais do que seja educação permanente e falta de agenda reservada para tal temática

- A falta de trabalho em equipe e integrado, a falta de compromisso profissional de alguns, a falta de auto avaliação e de apoio institucional, a falta de avaliação de desempenho dos profissionais dos municípios, a rotina de trabalho sem espaço reservado para Educação Permanente

- Uma definição fixa de agenda (encontros) para os profissionais participantes. 
- Planejamento, programação, otimizar tempo

- Dificuldade financeira e apoio da gestão

- Recursos humanos e financeiros, planejamento destas ações, e principalmente uma capacitação em Educação Permanente ou em Didática, pois as ações são ofertadas mas os métodos utilizados nem sempre são mais atrativos e eficientes.

- Sensibilização de gestores

- Por parte do regional de saúde, identifico as dificuldades financeiras do estado para realização de viagens e equipe de trabalho reduzida.

- Aumentar a visibilidade e potência da EPS enquanto ferramenta de gestão do trabalho.

- Dificuldades com agendas, profissionais desmotivados, falta de perfil em determinados atores.

- Agenda reservada e capacidade dos profissionais refletirem sobre suas práticas.

- Adesão dos profissionais.

- $\mathrm{RH}$ reduzido, sobrecarga de trabalho, disponibilidade e interesse dos servidores, apoio da gestão, compreensão da população, ausência de horário protegido para que a EPS aconteça de forma mais formalizada.

- Falta de conscientização, apoio e priorização da ferramenta enquanto potente transformadora das práticas em saúde.

- Perfil dos multiplicadores, interesse e comprometimento em alguns casos. Falta de formação/experiência em alguns casos.

- Atendimentos de média e alta complexidade

- Deficiência de recursos humanos no setor e falta de capacitação em metodologias ativas.

- Falta de motivação e perfil dos responsáveis em alguns casos, falta de apoio da gestão.

- Escassez de recursos humanos, excesso de conteúdo que deve ser dominado por um mesmo profissional

- Valorização, por parte dos gestores municipais, da educação permanente como ferramenta de melhoria da assistência prestada. Pouca sensibilização e informação dos profissionais em relação a essa ferramenta, como ferramenta de gestão do cuidado. Falta de $\mathrm{RH}$ para desenvolver e apoiar os municípios na implementação da Educação permanente no território.

5- O que você compreende por gestão em saúde?

- Compreendo gestão como uma forma de direcionar, de criar estratégias para o alcance de determinado objetivo. Articulando os pares, as políticas, as ferramentas disponíveis.

- É atingir objetivos através da mobilização de recursos humanos e materiais. Governabilidade.

- Gestão dos recursos financeiros e humanos para a promoção da saúde da população, com ideal conhecimento das políticas de saúde.

- Administrar a saúde pública no sentido de gerir/criar processos e programas.

- É a administração por um determinado ente, que por meio de articulação entre setores e pessoas, também aquisição de bens e serviços, possui o objetivo de proporcionar ou garantir o acesso à saúde para a população.

- Todo gerenciamento da saúde.

- Refere-se a atos de governo na administração da saúde

- Administrar orientar e fazer o ideal para a necessidade do usuário

- É a possibilidade de intervir sobre os condicionantes de saúde de forma a buscar a melhoria na qualidade de vida dos usuários e redução das vulnerabilidades.

- Saber avaliar e gerir processos de trabalho no âmbito da saúde de uma foram geral seja no município ou órgão público. Identificar grandes e pequenos dificuldades e procurar saná-los. Contar com equipe competente

- Saber administrar com sabedoria os recursos e deveres profissionais.

- Entendo como o ato de planejar, implantar e supervisionar as políticas e serviços de saúde. 
- Gestão em saúde diz respeito a forma de condução dos serviços de saúde, compreendendo sua complexidade e a dinâmica dos processos de trabalho, utilizando ferramentas de planejamento, monitoramento e avaliação de ações, indicadores.

- Modos de compreender e realizar as ações em saúde, que contemplam as diversas etapas ligadas a sua complexidade, sendo: atenção à saúde, recursos humanos e financeiros, estruturas, equipamentos e ambiência, resultados, avaliação e monitoramento das ações. Pode acontecer em diversos sentidos, como na relação gestão/profissionais; gestão/usuários; profissionais/usuários; profissionais/profissionais e usuários/usuários.

- Gerenciar processos e programas, criar e aplicar políticas de saúde.

- Gerenciamento de pessoas e serviços

- A gestão consiste em coordenar os processos de trabalho e da organização do sistema público de saúde com conhecimentos para a aplicação das políticas públicas e relações com os usuários do SUS.

- Processo de planejamento, organização, direção coordenação e controle.

- Entendo gestão em saúde um tarefa necessária para que as políticas públicas sejam eficientes. Compreende análise situacional do território, levantamento das necessidades de saúde definindo prioridades, planejamento e programação das ações em saúde, monitoramento e avaliação das ações de saúde.

- Gestão em Saúde é, na minha concepção, gerenciar ou atuar nas estruturas responsáveis pela organização do serviço para que o mesmo funcione de forma condizente com o esperado, envolve organizar ou apoiar a organização do processo de trabalho para que o mesmo atenda as demandas esperadas, seja por uma Política, por um Programa de Saúde, pela Instituição, etc. Também envolve o planejamento e a elaboração de diretrizes e Políticas em Saúde, envolve o apoio para a execução das mesmas, assim como o monitoramento e avaliação das ações.

- Um cuidado e aperfeiçoamento das técnicas, dos processos de trabalho e melhoria do atendimento na política pública.

- Avaliar as necessidades da instituição, gerenciar processos e programas, criar e aplicar políticas, gerenciar equipes

- Gerenciamento, avaliação e monitoramento das ações e serviços de saúde, incluindo processos de trabalho, planejamento e organização.

- É a aplicação de recursos como apoio institucional, conhecimentos técnicos e legislativos para organizar o setor saúde, ou no caso da SRS auxiliar os municípios nesta organização.

- Planejamento, monitoramento e avaliação de políticas e programas.

- Administração/gerenciamento/gestão dos serviços de saúde em seus diversos pontos de atenção e em complexidades diferentes.

- Gerir todo o sistema de saúde

- Ações gerenciais no âmbito da saúde, planejamento nos níveis municipal, regional, estadual, federal. Pensar políticas públicas em saúde, executar políticas já existentes. Trabalhar com planejamento orçamentário e financeiro.

- A capacidade de tomada de decisão e realização de planejamento efetivo.

- Avaliar as necessidades da instituição, gerenciar processos e programas, criar e aplicar políticas, garantir o acesso dos pacientes ao serviço de saúde e com qualidade e gerenciar equipes.

- Realizar o planejamento, implantação e supervisão das ações, serviços e projetos de Saúde Pública para implementação das políticas públicas e relações com os usuários do SUS.

- Gestão em saúde pressupõe governança dos sistemas de apoio logístico, redes assistenciais e das políticas públicas em saúde como um todo.

- Todas as atividades de planejamento, execução, monitoramento e avaliação de ações de saúde.

- Gerenciar processos e programas, criar e aplicar políticas, garantir o conforto e a segurança dos pacientes e gerenciar equipes são algumas das atribuições da área de gestão em saúde. 
- É a forma de usar os recursos disponíveis para um resultado mais efetivo.

- Cargos e funções estratégicos de liderança e tomada de decisão em saúde.

- Organização dos processos de trabalho de forma a melhorar a qualidade dos serviços, adequar à demanda, visando o cumprimento dos princípios do SUS

- É a capacidade de direcionar recursos humanos e materiais em direção aos objetivos da instituição de saúde, maximizando os resultados, melhorando a qualidade da assistência prestada e reduzindo custos desnecessários.

6- Como a gestão em saúde se aplica em sua realidade cotidiana de trabalho?

- Se aplica ao momento que se pensa estrategicamente, que se utiliza das ferramentas adequadas para apoiar na operacionalização das atividades municipais.

- Ao atuar em uma área, devo conhecer essa área, planejar minhas ações, porém é necessário saber a disponibilidade e qualidade de recursos humanos e materiais que tenho.

- Aplicação prática das políticas públicas

- No gerenciamento e aplicação das políticas públicas de saúde.

- Por meio das nossas funções de apoio institucional, supervisão, monitoramento, gerenciamento e implantação das políticas e programas de saúde aplicadas aos municípios.

- Somos responsáveis por auxiliar os municípios na gestão da AB.

- O Núcleo de atenção primária da SRS auxilia os municípios nos processos de gestão da saúde municipais.

- Orientando e reunindo com Gestores para atuação em sua realidade.

- Por meio das reuniões de CIR, Conferências de Saúde, Reuniões Técnicas, ações em datas comemorativas e outras.

- Muito aberta, com vários projetos, enquanto GRS trabalhar bem com todos os municípios e população.

- Cada membro da equipe possui suas atribuições, sem que um avance na tarefa doutro, sempre existindo o trabalho em equipe e parceria.

- Trabalhamos rotineiramente com ela, visto que nossas atribuições são as de gestão: planejar, implantar e acompanhar as políticas públicas de saúde em nossa regional.

- Como gestão estadual, contribuímos com os municípios no sentido de levar informações em relação às políticas vigentes, que dão as diretrizes de organização do sistema único de saúde. Tais diretrizes devem nortear as formas de organização dos processos de trabalho a nível municipal, sendo o estado responsável por auxiliar no monitoramento e avaliação desses serviços e de prestar apoio institucional aos municípios no enfrentamento dos problemas.

- Nas práticas e ações na relação intra-setorial, intersetorial na SRS, com o nível central, gestão municipal e equipes. Em momentos de pactuações diversas, nos vários níveis.

- No apoio institucional aos municípios.

- Diariamente no desenvolvimento de minhas atividades.

- A todo momento fazemos gestão em saúde.

- No alcance das metas e discussão dos indicadores em saude, como norte da atenção.

- Confesso que a gestão em saúde é regular, mas procuro analisar os indicadores e resultados que monitoro e procuro apoiar os municípios na melhoria dos resultados.

- A gestão em saúde está muito presente no meu cotidiano de trabalho, uma vez que acompanhamos os municípios no desenvolvimento das ações das Políticas e Programas de Saúde.

- Por meio do planejamento e monitoramento das ações, com a implantação de uma gestão participativa e com a implantação de processos de trabalho unificados em todas as equipes.

- Através do planejamento, programação e rotinas

- Enquanto regional, nós damos apoio aos municípios, auxiliamos na avaliação e monitoramento das ações, além de participação da organização dos processos de trabalho. 
- Meu trabalho é baseado exclusivamente na gestão em saúde.

- Apoio técnico, replicação de capacitações, monitoramento de programas e ações.

Atuamos na gestão estadual das políticas públicas de saúde da SES/MG na região Norte de Minas Gerais, que possui 53 municípios adstritos a SRS Montes Claros.

- Através da Gestão participativa, valorizando o trabalho e o trabalhador

- Na prática cotidiana em serviço de saúde pública.

- Nos planejamentos realizados para melhoria dos serviços ofertados pelos municípios.

-Contribuo com o gestor e as equipes de atenção básica, na avaliação, gerenciamento de $\mathrm{RH}$.

- Visão sanitária voltada para a organização de serviços e programas de saúde segundo um novo modelo de atenção (prevenção/ promoção/ doenças crônicas)

- De forma incipiente, pela falta de governabilidade para solucionar a maior parte dos problemas com que lido.

- Diariamente, minha função é apoiar os municípios na execução de ações de promoção da saúde nos municípios.

- Sem estrutura

-No apoio aos municípios com relação aos programas e assuntos da Atenção Primária à Saúde.

- Orientação e assessoria aos gestores municipais.

- No monitoramento e avaliação de indicadores de desempenho das políticas de saúde e apoio institucional ao municípios de nossa região de saúde.

- A atenção primária à saúde é descentralizada a nível municipal, o que dificulta a gestão direta em saúde como instância estadual. Porém, atuamos no apoio institucional aos municípios na execução das ações a nível municipal, analisando informações estratégicas, orientando em relação às condutas e protocolos vigentes, auxiliando na formação e qualificação de recursos humanos e discutindo os processos de trabalho a nível municipal.

7- Como sua formação profissional, contribui para à aplicabilidade dos conceitos acima, em sua prática cotidiana?

- O fato de ser enfermeira, auxilia muito. É algo incutido dentro de nós, além de ser um dos poucos profissionais de saúde que tem em sua formação conteúdo da administração e da educação.

- Sim

- Aplicação prática das políticas públicas

- No gerenciamento e aplicação das políticas públicas de saúde no que diz respeito ao cuidado com o paciente.

- Com a agregação de conhecimentos e experiências adquiridos ao longo da vida profissional, que asseguram maturidade na condução do serviço.

- A Psicologia trabalha tanto com aspectos da área de saúde como da área de humanas.

- Através da organização dos processos de trabalho para enfrentamento das demandas da saúde.

- Nada.

- Atuando de forma interna e de forma direta com os profissionais e gestores, fazendo alinhamentos, avaliação de resultados, e buscando a melhoria dos processos de trabalho e da qualidade dos serviços.

- Conhecimento Administrativo, logística, cultural e conhecedor da área da saúde.

- Saber lidar com vários tipos de pessoas e personalidades.

- Trabalho também com as políticas públicas de Saúde Bucal e, portanto, vivencio minha formação em todo o meu processo de trabalho.

- Como enfermeira, é fundamental o conhecimento inicial de administração aplicada à saúde. Além disso, o curso de mestrado em saúde coletiva que estou realizando também tem acrescentado bastante conteúdo teórico para o desenvolvimento dessas ações.

- O entendimento do processo de trabalho da Atenção Primária à Saúde a partir da minha formação profissional desde a finalização da graduação tem contribuído na gestão em 
saúde nos momentos de encontros com os atores envolvidos nos vários momentos, desde a aplicabilidade de alguns programas até a negociação de situações que envolvam a realização de novas ações ou a melhoria das já existentes.

- Sou nutricionista, atualmente não trabalho com os programas de nutrição e alimentação.

- Durante minha formação tive 4 disciplinas de gerenciamento, porém a aplicabilidade na prática é diferente do que é vivido na universidade.

- Buscando conhecimento no campo da ciência dos fatores determinantes e condicionantes da saúde, além de planejar das respostas aos processos de saúde e doença através de ações voltadas para a necessidade da população.

- A minha formação na área de enfermagem contribui para isso bem como a minha experiência profissional em ter trabalhado no âmbito municipal.

- A minha formação profissional abordou muito o conceito de gestão em saúde, principalmente voltada à Saúde Pública, o que acredito ter sido muito importante para a minha formação pessoal e profissional.

- O serviço social me auxiliou na escuta qualificada, tanto do funcionário quanto dos profissionais que estão sob a minha coordenação.

- Com as experiências adquiridas e a compreensão dos saberes vivenciados.

- Foi de suma importância a grade curricular dos cursos feitos, tanto graduação quanto pós, trazerem em seus conteúdos o planejamento e gestão do SUS, para termos um contato inicial com as práticas de instrumentos utilizados.

- Minha pós graduação em Micropolíticas da Gestão e Trabalho em Saúde foi um curso voltado especificamente para meu trabalho cotidiano, o qual me deu muitos subsídios para desenvolver meu trabalho com mais conhecimento técnico.

- Avalio que a enfermagem traz muitos conceitos e ferramentas para gestão em saúde e esse conhecimento contribui muito para a minha prática profissional.

- Como crença de que só através da escuta qualificada, da construção coletiva podemos fazer mudanças no modo de fazer saúde

- É fundamental. A partir dela baseio todo o trabalhado desenvolvido junto aos municípios.

- A enfermagem tem em sua essência a questão direcionada a educação e formação.

- Replicando conhecimento aos outros profissionais.

- Minha formação possibilitou o conhecimento da Rede de Atenção, políticas e programas de saúde, vivência no SUS, etc.

- Contribui bastante na compreensão da gestão a partir do olhar assistencial. Minha formação na graduação foi mais focada na administração e assistência de enfermagem do que nas questões de saúde públlica - hoje o currículo do curso já mudou, mas a prática profissional é que me atualiza e me agrega mais conhecimento.

- Totalmente. Minha formação acadêmica e experiência profissional me capacita à realização da minha função.

- Contribuem para ampliar ... ela enfatiza essa separação entre os conceitos de teoria e prática

- Desde a época da formação universitária sempre foi muito debatido a importância da educação permanente na saúde e de uma gestão qualificada.

- Muito, tanto a formação básica quanto os cursos subsequentes contribuem muito para minha prática profissional.

- Além de outros programas, sou referência técnica em Saúde Bucal, e minha formação facilita a realização do apoio institucional, discussão de fluxos, etc.

- A especialização em Preceptoria no SUS, ampliou minha visão sobre o SUS, pois pude conhecer diversos profissionais, de diferentes áreas de atuação e diferentes setores do SUS.

- A formação como enfermeira e a experiência em equipe de ESF, permite ter uma noção maior da realidade, das dificuldades de execução das ações na assistência direta e de certa forma facilita a compreensão das necessidades e aplicação das ações de educação permanente, de capacitação dos profissionais. Além disso, permite uma reflexão mais crítica dessas necessidades, uma vez que muitos conhecimentos são inerentes ao processo de formação profissional e outras demandas são originadas da prática 
assistencial e requerem aperfeiçoamento constante.

8. Em seu trabalho, você realiza atividades de apoio técnico (à nível de Atenção Primária da Saúde) aos municípios da jurisdição da regional de saúde?

Sim

Sim

Não

Sim

Sim

Sim

Sim

Sim

Sim

Sim

Sim

Sim

Sim

Sim

Sim

Sim

Sim

Não

Sim

Sim

Não

Sim

Sim

Sim

Sim

Sim

Sim

Sim

Sim

Não

Sim

Sim

Sim

Sim

Sim

Sim

Sim

Sim

9- Se sim, quais seriam?

- Ações de capacitação, avaliação e monitoramento das ações de atenção primária.

- Orientações de conduta com capacitação aos enfermeiros e médicos responsáveis pelo atendimento.

- Avaliação e análise dos dados epidemiológicos para planejamento conjunto das ações necessárias.

- Supervisão de campanhas de vacinação.

- Monitoramento das ações de vigilância em saúde.

- Capacitações, cursos, intervenções, monitoramentos e eventos de congratulações.

"1-Realização de visitas de supervisão técnica em atendimento SAPS/SES$M G$

2-Realização de reuniões de alinhamento com os coordenadores de Saúde 
Bucal, tendo como foco os processos de trabalho da Atenção Primária e Centro de Especialidades Odontológicas

3-Realização de reuniões de alinhamento com coordenadores de Saúde da Família e NASF-AB, tendo como foco os processos de trabalho

4-Condução dos processos para credenciamento de equipes de Saúde da Família, Saúde Bucal e NASF-AB

5-Condução dos processos para implantação ou reorganização de Centros de Especialidades Odontológicas

6-Suporte para implantação e condução do Programa de Melhoria do Acesso e da Qualidade da Atenção Básica (PMAQ-AB)

7-Suporte/acompanhamento dos indicadores de Saúde Bucal e Saúde da Família

8-Acompanhamento e suporte ao Programa de Odontologia Hospitalar

9-Capacitação e suporte para implantação da Estratégia e-SUS

10-Implantação e monitoramento dos Laboratórios Regionais de Próteses Dentárias (LRPD)

11-Acompanhamento da avaliação do Cofinanciamento da Atenção Primária

12-Representação do Napris nas reuniões de Câmara Técnica, CIR e CIRA

13-Suporte para o Programa Mais Médicos, quando demandado

14-Suporte ao Programa de Atenção à Saúde Indígena

15- Suporte ao monitoramento das obras de reforma, ampliação e construção de UBS.

16-Fiscal de convênio de obras

17- Capacitação, condução e monitoramento do Programa Nacional de Controle do Tabagismo

18- Suporte ao Programa Nacional de Atenção à Saúde dos Privados de Liberdade

19- Implantação da Carteira de Serviços da Atenção Primária à Saúde

20- Suporte aos Programas de Atenção à Saúde da criança, adolescente, adulto e idoso.

21- Monitoramento dos casos de microcefalia em parceria com à Coordenação de Saúde da Mulher/SES-MG

22- Realização de cursos e palestras em atendimento à UFVJM"

Apoio institucional"

- Conhecimento e divulgação das políticas públicas de saúde.

- Apoio técnico ao NASF.

- Apoio técnico para ampliação das ESF.

- Monitoramento e avaliação das atividades das equipes.

- Reunindo com gestores e Profissionais que atuam na área da Saúde com referência a Atenção Básica e programas relacionados dentro das Legislações Vigentes.

- Acompanhamento dos Programas e discussão com os profissionais

- Referência Técnica: Privados de Liberdade, Saúde do Homem, Educação Permanente, Saúde dos Adolescentes, Ouvidoria, Telessaúde, Saúde do Idoso, Política de Humanização

- Visitas técnicas rotineiras, suporte para os sistemas de informação e sistemas WEB, monitoramento de obras, composição de equipes e profissionais, treinamentos, etc.

- Implantação, supervisão e acompanhamento das políticas públicas ligadas à atenção primária.

- Auxiliando nas demandas relacionadas aos sistemas de informação (e-SUS, SISVAN, Bolsa Família......), oferecendo capacitações nas áreas técnicas das quais sou referência, discutindo diretrizes de organização dos serviços de saúde, repassando informações de políticas e programas vigentes.

- Relacionadas aos programas: PMAQ, estratégia e-SUS, Arboviroses na APS, Saúde do Homem, Saúde do Idoso, Doenças Crônicas. 
- Apoio Institucional nos programas: NASF/Privados de Liberdade e Saúde Indígena. capacitações.

- Apoio institucional na implementação das políticas de saúde relacionadas a atenção primária em saúde.

- Referência Técnica da Alimentação e Nutrição, Referência técnica do NASF, referência técnica do programa bolsa família.

- Relacionados aos temas da Política Estadual de Promoção à Saúde e dos Programas da Promoção à Saúde, além da Política Nacional de Práticas Integrativas e Complementares em Saúde.

- Assessoria, apoio institucional, orientação, reuniões técnicas, oficinas, cursos e capacitações direcionadas aos profissionais técnicos de saúde dos municípios.

- As atividades de apoio técnico envolvem desde o apoio por telefone, e-mail, reuniões e capacitações a apoio presencial com auxílio na organização dos serviços.

- Apoio institucional e capacitações/oficinas.

- As mais relevantes são a realização de supervisão técnica e a capacitação de profissionais e gestores.

- Oficinas de Acolhimento, rodas de conversas

- Apoio institucional. Referência técnica para políticas públicas e programas assistenciais. Apoio a Coordenação APS e gestão dos municípios.

- Apoio institucional para o desenvolvimento de todas as Políticas Públicas de Atenção Primária à Saúde.

- Apoio institucional às equipes de atenção básica e Saúde Família, NASF, Saúde Bucal; processos de trabalho; protocolos e diretrizes clínicas.

- Reuniões técnicas, treinamentos, capacitações, assessoria in locu, por telefone e por meio eletrônico em relação aos programas de promoção da saúde.

apoiar os municípios na implementação da Política Estadual de Promoção da Saúde (POEPS), a Resolução 5250/2016 recomenda a elaboração do Plano Municipal de Promoção da Saúde.

- Capacitações, apoio nas dificuldades, auxílio em estabelecimento de fluxos mais adequados, etc.

- Reuniões técnicas, oficinas, simpósios e workshops relacionados às políticas e programas de Promoção da Saúde. No dia-a-dia esse apoio aos municípios acontece ainda pessoalmente, por telefone ou meio eletrônico.

- Visitas técnicas, capacitações

- Como referência técnica de sistemas de informação (e-SUS, SISVAN, Micronutrientes, entre outros), na qualificação e formação de recursos humanos, promovendo capacitações, reuniões, oficinas e outros, na divulgação de manuais, procedimentos operacionais e protocolos vigentes.

10- Na sua opinião, como a Educação Permanente, pode contribuir enquanto dispositivo de gestão do SUS?

- Na minha visão, pode contribuir possibilitando a transformação das práticas cotidianas, e no alcance dos objetivos do SUS. O gestor precisa estar sensibilizado e utilizando-se da educação permanente, para trabalhar os problemas cotidianos e desenvolver profissionais mais críticos.

- Para qualificar a atenção à saúde, os processos formativos, as práticas de educação em saúde, além de incentivar a organização das ações e dos serviços numa perspectiva intersetorial.

- Instruindo melhor os profissionais envolvidos.

- Quando contribui para aperfeiçoamento e mudanças de práticas.

- Instituindo um programa de educação permanente que de fato responda às necessidades locorregionais.

- Um dos grandes gargalos do SUS é a gestão. Qualificando-se a gestão através da EP, teremos melhores condições de Ihe lidar com os problemas do dia a dia. 
- Para um melhor balizamento das equipes da ESF perante aos princípios e diretrizes do SUS. Maior resolutividade da atenção primária dos municípios;

- Muito em todos sentidos hoje a muita mudança nas legislações e rotatividade de profissionais

- A partir da identificação dos gargalos e necessidades em saúde os profissionais e gestores podem avaliar as principais vulnerabilidades e atuarem para a melhoria da qualidade e atenção em saúde.

- Elaboração e realização de diretrizes para melhor andamento dos trabalhos com maior capacidade de gerir

- Contribui como um veículo de proximidade de saberes, onde o compartilhamento de ideias favorecem o desenvolvimento da ações.

- A Educação Permanente é um facilitador para que a gestão das políticas ocorra de forma contínua e efetiva.

- Por ser um instrumento de problematização a partir das práticas cotidianas, a educação permanente possibilita que os profissionais identifiquem suas necessidades reais e favorece a troca de experiências e saberes no desenvolvimento de soluções para os problemas ou dificuldades. Além disso, a educação permanente permite dar maior visibilidade às demandas dos profissionais, por parte dos gestores, principalmente por significar um processo de construção coletiva.

- Na melhoria das várias faces do processo de trabalho nas várias relações possíveis; na percepção e diagnóstico de situações problemas e em sua solução; na formação de equipes mais capacitadas e preparadas para o enfrentamento de diversas situações.

- Contribui na qualificação dos profissionais que atuam nas Políticas Públicas de Saúde.

- É um fator importantíssimo no desenvolvimento do profissional, que além de se sentir valorizado reproduz conhecimento e saberes para a população

- A educação permanente contribui para a qualificação das ações em saúde, sendo orientadora e facilitadora das práticas assistenciais diárias, o que favorece os processos de gestão.

- O processo de educação permanente na minha opinião é o principal fator para a resposta positiva aos determinantes de boa saúde.

- Através da reflexão das práticas cotidianas do trabalho os profissionais podem ser capazes de propor melhorias para resolver problemas e consequentemente podem melhorar o cuidado em saúde.

- A educação Permanente é essencial para o SUS e deve ser valorizada cada vez mais, pois sabemos que os profissionais que integram as Equipes de Atenção Primária tem formação variada no campo de Saúde Pública, e que a visão do profissional em relação aos princípios da Atenção Primária como corresponsabilização, vínculo, cuidado integral, avaliação de riscos e vulnerabilidade, etc, para uma atuação efetiva e de impacto positivo na saúde dos usuário do SUS ainda não é uniforme e muitas vezes aquém do desejável. Por isso a Educação Permanente tem que ser trabalhada no sentido de organizar o serviço e também é um espaço para trabalhar em conjunto as demandas daquele território e as formas de se intervir de maneira mais eficaz nos nós críticos que forem sendo identificados. É também um espaço para se formar/atualizar em relação as condições de saúde mais prevalentes ou de importância para os profissionais e território.

Resumidamente, o aperfeiçoamento da prática de trabalho tanto teórico quanto prático, visa implantar diretrizes únicas para a condução das rotinas da atenção primária e assim, melhorar a qualidade do atendimento para o usuário.

- Através do reconhecimento dos problemas e dificuldades vivenciadas no cotidiano

- Atualização e qualificação de profissionais

- A educação permanente tem o potencial modificador da realidade, incentivador do pensamento e reflexão das práticas e consequente melhoria do apoio institucional

- Auxiliando na qualificação da atenção à saúde.

- A EP tem papel essencial na gestão do SUS, visto que desenvolve potencialidades, ajuda a refletir sobre a prática e a melhorar a qualidade dos serviços prestados.

- A EPS, propõe que na roda façamos discussões dos processos de trabalho, permitindo 
trocas de ideias e mudanças de performance.

- Fundamental, contribuindo para atualização de saberes e práticas profissionais. Nos faz repensar a prática cotidiana em saúde.

- Garantindo reflexão e avaliação sobre as práticas de cada um dos profissionais em seus espaços de trabalho.

- Sim.

- Na integração e qualificação dos profissionais para uma assistência com mais qualidade conforme a demanda local.

- A EP contribui muito no sentido de qualificar as práticas em saúde a partir da transformação destas práticas, seja pela desconstrução, construção ou reconstrução de conceitos. Entendo que é a melhor estratégia de fortalecimento do SUS porque impacta em todas as esferas da gestão.

- Aperfeiçoando o planejamento, a execução, monitoramento, avaliação e replanejamento das ações de saúde e qualificando as processos de trabalho.

- Formação e Educação Permanente e Educação Popular em Saúde.

- A Educação Permanente fortalece e empodera a equipe de saúde para o processo de trabalho mais qualificado.

- Podemos aprimorar os processos de gestão do SUS em diversas dimensões, como melhorar a qualidade técnica dos serviços prestados, melhorar o relacionamento interpessoal entre os trabalhadores e também com a população, otimizar investimentos financeiros, agilizar as intervenções necessárias.

- A Educação Permanente possibilita que o profissional repense os processos de trabalho e dissemine as informações para o restante da equipe. O profissional pode ter contato com novas ferramentas de gestão, que poderão aprimorar e nortear suas práticas profissionais.

- Principalmente no aprimoramento dos processos de trabalho. Quando se pensa em educação permanente, deve-se ter em mente o desenvolvimento de ações que irão qualificar a assistência prestada.

11- Caso ache necessário, use livremente este espaço, para abordar algum assunto ou situação relacionado à temática desta pesquisa que não tenha sido retratado nas perguntas acima.

- Seria importante a implantação de educação permanente utilizando as Unidades regionais como agente facilitador dos processos.

- Educação permanente não é apenas direcionada somente para cursos e capacitações de profissionais e muito mais do que isso. Pode-se realizar EPS em vários órgãos, vários seguimentos de profissionais, dentro de um ambiente de trabalho e município

- A política de educação permanente deve ser implementada e introduzida em todas as esferas. O tema se torna imprescindível para que o trabalho no SUS seja sempre realizado com competência, garantindo aos profissionais e usuários, total suporte qualificado.

- Educação permanente deveria ser contabilizado como meta estratégica em todos os âmbitos do sus.

- Infelizmente muitos profissionais tem um entendimento que educação permanente em saúde e educação continuada. Inclusive foi liberado um recurso do governo federal para EPS na atenção básica e alguns municípios fizeram um plano com uma relação de capacitações a serem realizadas que serão contempladas com o recurso.

- Acredito que as questões contemplaram a temática.

- Penso que está pesquisa veio num momento oportuno em que estamos discutindo a EPS nos territórios.

- "Levanto a bandeira" de que as universidades precisam estar mais integradas à gestão estadual do SUS, com estágios curriculares e integração ensino-serviço efetiva. 
